\title{
Are Lending Relationships Beneficial or Harmful for Public Credit Guarantees? Evidence from Japan's Emergency Credit Guarantee Program*
}

\author{
Arito Ono $^{* *}$, Iichiro Uesugi ${ }^{* * *}$, and Yukihiro Yasuda ${ }^{* * * *}$
}

This draft: May 2012

Initial draft: June 2010

\begin{abstract}
This paper examines the effectiveness of Japan's Emergency Credit Guarantee (ECG) program set up during the financial turmoil following the failure of Lehman Brothers, in increasing credit availability and improving the ex-post performance of small businesses. In particular, using a unique firm-bank matched dataset, the paper examines whether lending relationships enhanced or dampened the effects of the ECG program. It is found that the ECG program significantly improved credit availability for firms using the program. However, when it is a relationship lender (main bank) that extends an ECG loan, the increased availability is partially, if not completely, offset by a decrease in non-ECG loans by the same bank. Further, propensity score matching estimations show that the ex-post performance of firms that received ECG loans from the main bank deteriorates more than that of firms that received non-ECG loans. We do not find such loan "substitution" or performance "deterioration" effects when a non-main bank extends ECG loans. Our findings suggest that close firm-bank relationships may have perverse effects on the efficacy of public credit guarantees.
\end{abstract}

Keywords: loan guarantees, relationship lending, small business credit

\section{JEL classification: G21, G28, G38}

\footnotetext{
* The views expressed in this paper are ours and do not necessarily reflect those of any of the institutions that we are affiliated with. We would like to thank Takeo Hoshi, participants at Hosei University, participants of the APD Finance Seminar at the International Monetary Fund and the 12th Macroeconomics Conference at Hitotsubashi University, and members of the Study Group on Changes in Financial and Industrial Structures at the RIETI (Research Institute of Economy, Trade and Industry) for helpful comments. Any remaining errors are our responsibility.

${ }^{* *}$ Research Department, Mizuho Research Institute; arito.ono@mizuho-ri.co.jp.

**** Institute of Economic Research, Hitotsubashi University and RIETI; iuesugi@ier.hit-u.ac.jp.

${ }^{* * * *}$ Faculty of Business Administration, Tokyo Keizai University; yyasuda@tku.ac.jp.
} 


\section{Introduction}

The financial crisis that erupted after the failure of Lehman Brothers in the fall of 2008 prompted governments around the world to introduce various policy measures to help firms in distress, such as tax reductions, export facilitation measures, and measures to enhance firms' access to credit. One of the most frequently employed measures is credit guarantee programs, which aim at improving credit availability for firms. For instance, OECD (2009) shows that 19 out of 23 OECD member countries introduced or strengthened credit guarantee programs following the onset of the crisis.

Japan was among these countries. Along with a variety of other measures, the government introduced, at the end of October 2008, the Emergency Credit Guarantee Program (ECG program hereafter). This program is of particular interest to researchers because it is one of the largest single credit guarantee programs in OECD countries, with planned guarantees amounting to 36 trillion yen (approximately 400 billion U.S. dollars). The purpose of this study is to empirically examine with the help of a unique firm-bank matched dataset the effectiveness of this ECG program in increasing credit availability for firms and improving their ex-post performance.

Although credit guarantee programs to assist small businesses in difficulties are widely used around the world, existing theoretical and empirical studies have yet to reach firm conclusions on their economic impact. In one strand of theoretical studies, credit guarantees may attenuate the credit rationing under asymmetric information between a borrower and a lender à la Stiglitz and Weiss (1981), and may result in funding profitable projects that would not be realized without government intervention (Mankiw, 1986; Gale, 1990, 1991). Another strand in the literature suggests, however, that if the unfettered market (pooling) equilibrium under asymmetric information is such that some projects with a negative net present value are funded, then credit guarantees may exacerbate the "overlending” problem (de Meza and Webb, 1987; de Meza, 2002). Empirical studies using micro data have generally found a positive impact of credit guarantees on the availability of credit to small businesses (Cowling, 2010; Riding, Madill, and Haines, 2007; Uesugi, Sakai, and Yamashiro, 2010; Zecchini and Ventura, 2009). However, the effect on the ex-post performance of credit guarantee users appears to be mixed (see, e.g., Riding and Haines, 2001; Kang and Heshmati, 2007; Oh, Lee, Choi, and Heshmati, 2009 that find positive effects; Uesugi, Sakai, and Yamashiro, 2010 that finds negative effects). 
Credit rationing (or overlending) under asymmetric information does not always necessitate the use of government interventions to credit markets including credit guarantees. Many of the studies on small business financing have argued that relationship lending reduces informational friction and enhances credit availability for firms, either in normal times or during a financial crisis (Angelini, Di Salvo, and Ferri, 1998; Cole, 1998; Jiangli, Unal, and Yom, 2008; Petersen and Rajan, 1994). However, an issue that has not been addressed in the literature so far is how firm-bank relationships affect the economic effects of public credit guarantee programs.

On the one hand, if a relationship lender uses the credit guarantee program in order to supplement its efforts to help borrowers in temporary distress, then it is likely that the provision of guaranteed loans will be associated with an increase in non-guaranteed loans and result in an improvement in the ex-post performance of borrower firms. On the other hand, close firm-bank relationships may have negative effects if the credit guarantee program provides the relationship lender with an opportunity to exploit its informational advantages. Similar to the problem of conflicts of interest for bank underwriting of corporate bonds (in which an informed bank underwrites and distributes corporate bonds of low quality firms to outside investors in order to redeem its existing loans), an informed relationship lender may switch loans to risky firms from non-guaranteed to guaranteed loans, thus transferring the credit risk to the public credit guarantee program. If this is the case, we would observe a decrease in non-guaranteed loans and a deterioration in the ex-post performance of borrowers that obtained guaranteed loans from relationship lenders.

Using a unique firm-bank matched panel dataset of about 2,500 observations during the current financial crisis, we examine whether the ECG program was effective in increasing the availability of small business loans and improving borrower firms' performance. In particular, we investigate whether lending relationships (defined as a situation where the lender is the main bank of the firm) enhanced or dampened the effects of the ECG program.

Our dataset contains a range of information that is particularly valuable for our analysis. First, we can identify user firms of the ECG program as well as non-users. Thus, we are able to identify the factors that affect the availability of credit both for users and non-users of the program and to determine the effects of the program. Second, and most importantly, we can identify the "main bank" and non-main banks of a firm. This allows us to explore how lending 
relationships interact with the usage of the ECG program, which is the primary concern of this paper. Further, for each firm-bank match, we can identify the amount of individual ECG loans and the amount of total loans outstanding, including both ECG loans and non-ECG loans provided by the same bank. Hence, we are able to make inferences on the changes in a bank's existing loans at the time the bank extends an ECG loan. Finally, although only for a short-time horizon (one year after ECG loans were provided), we have ex-post performance variables that are useful in evaluating the efficacy of the ECG program.

The major empirical findings are as follows. The ECG program significantly improved the availability of credit for program user firms. However, when it is the main bank of a firm that extends an ECG loan, the positive effect of the program is partially, if not completely, offset by a decrease in non-ECG loans by the main bank. Further, ex-post creditworthiness (the credit score one year later) of ECG program users deteriorated more than that of non-users. Such loan "substitution" effects do not necessarily occur when ECG loans were extended by non-main banks. These findings suggest that close firm-bank relationships may have perverse effects on the efficacy of the public credit guarantees program.

The remainder of the paper is organized as follows. Section 2 briefly describes the credit guarantee system in Japan, with particular attention paid to the ECG program. Section 3 then presents our empirical hypotheses, while Section 4 describes the data, variables, and empirical approach employed. Section 5 presents the empirical results. Finally, Section 6 concludes.

\section{Public Credit Guarantees in Japan}

\subsection{The Credit Guarantee System}

Even before the recent financial crisis, the Japanese government had introduced a variety of programs to facilitate the flow of funds to small and medium enterprises (SMEs), including direct lending by government-backed financial institutions as well as loan guarantee schemes. In terms of the amount of loans outstanding, government credit guarantees have been used more extensively than direct loans. Further, the use rate of guarantees is far higher than that of 
direct loans, with nearly 40 percent of all Japanese SMEs having received guarantees.

Three parties are involved in credit guarantee transactions in Japan: a small business borrower, a financial institution, and a credit guarantee corporation, which is financially backed by the government. In order to obtain guaranteed loans, small businesses have to first file an application with a credit guarantee corporation. In practice, most applications are filed by financial institutions on behalf of small business borrowers, although some firms file applications on their own behalf. In the first case, the financial institution may conduct a preliminary screening before it actually delivers the application to a credit guarantee corporation. Next, the credit guarantee corporation examines the application and makes a credit decision. Finally, based on a letter of approval from the credit guarantee corporation, the financial institution extends a loan to the small business. The borrowing firm is then required to pay a guarantee premium, with the amount in principle depending on the credit risk of the firm. The average premium is about 1.35 percent of the total loan amount extended. In the case that the firm is unable to repay its debt to the bank, the debt is covered by the credit guarantee corporation, which takes over the loan claim from the bank. In most cases credit guarantees extend to 80 percent of the loan amount. ${ }^{1}$ Finally, the credit guarantee corporation, or a debt collection agent acting on behalf of it, will try to collect part or all of the loan, for example by assisting in the restructuring of the firms a process that may take considerable time.

\subsection{The Emergency Credit Guarantee Program}

In response to the financial crisis that started in the fall of 2008, the Japanese government introduced various stimulus measures in order to alleviate the massive adverse shocks to the economy. These measures include a temporary corporate tax reduction, lump-sum cash handouts to households, and larger employment adjustment subsidies. Moreover, supplementing the regular credit guarantee scheme just discussed, the government on October 31, 2008, introduced the ECG program as a temporary rescue measure. The program is scheduled to expire at the end of March 2011. With credit guarantees of up to 36 trillion yen, the size of the ECG program is unprecedented, surpassing that of a previous

${ }^{1}$ Until October 2007, such credit guarantees extended to 100 percent of the loan amount, but changes in government policy subsequently reduced that to 80 percent. 
temporary program, the Special Credit Guarantee Program (SCG program) (30 trillion yen) implemented from October 1998 to March 2001. The size of the credit facility is equivalent to about 15 percent of total SME loans outstanding in Japan. By the end of March 2010, the amount of ECG loans extended stood at almost 20 trillion yen.

In comparison with the regular credit guarantee program, the ECG program has the following institutional features. First, the ratio of credit covered by credit guarantee corporations is 100 percent; thus, banks that extend ECG loans bear no credit risks. Second, the maximum duration of an ECG loan is ten years, whereas that of a regular credit guaranteed loan is seven years. Third, guarantee premiums, most of which are set at about $0.75-0.80$ percent of the loan amount, are lower than the average premium charged to regular program users. Moreover, in contrast with the regular program, where the premium varies between 0.45 to 1.9 percent with the average of 1.15 percent depending on the borrowing firm's credit risk, the premium for ECG loans is a fixed percentage set by each credit corporation in order to reduce the payment burden for risky borrowers. Finally, while the risk weight of regular credit guaranteed loans under the Basel II Capital Accord is 10 percent, the risk weight of the ECG loans is set to 0 percent in order to facilitate the use of the ECG program by banks.

As mentioned, the Japanese government implemented a similar temporary credit guarantee program, the SCG program, in the midst of the financial crisis during the late 1990s. The purpose of the SCG program was to alleviate the severe credit crunch for small businesses caused by the non-performing loan problem faced by Japanese banks. Thus, it should be noted that the current situation is quite the opposite of that which prompted the SCG program; that is, whereas the SCG program was launched in response to problems in the financial sector, the ECG program was introduced to deal with the sharp decline in business activity and firms’ worsening financial position.

Comparing the ECG program and the SCG program, both similarities and differences can be observed. As for similarities, the credit coverage by credit guarantee corporations in both programs is 100 percent. $^{2}$ In addition, both programs in principle do not ask borrower firms to pledge collateral.

On the other hand, there are also substantial differences between the ECG and the SCG program. First, the loan

\footnotetext{
${ }^{2}$ However, at the time of SCG program, the credit coverage of the regular program was also 100 percent, while at present it is only 80 percent.
} 
screening policy of the ECG program is stricter than that of the SCG program. A loan application under the SCG program could be rejected only if a prospective borrower breached certain minimum conditions such as not having significant negative net worth, not being tax delinquent, not having defaulted, and not having engaged in balance sheet window dressing. In contrast, under the ECG program, approvals are not automatic and are subject to a strict screening process. The difference may be due to the huge deficits that credit guarantee corporations currently have, as well as widespread criticism of the SCG program with regard to its lenient screening policy and resulting misuse of funds, as evidenced by a number of anecdotes. ${ }^{3}$ On the other hand, in terms of the maximum size and duration of loans, the ECG program allows user firms to borrow a larger amount for a longer period of time than the SCG program: the maximum amount and duration of ECG loans are 280 million yen and ten years, respectively, whereas those of the SCG loans were 250 million yen and seven years, respectively.

\section{Empirical Hypotheses}

\subsection{Effects of Credit Guarantees}

The economic effects of public credit guarantees have been analyzed in a variety of theoretical studies. Many of these studies are based on the presumption that the adverse selection problem under asymmetric information between borrowers and lenders results in an undersupply, or rationing, of credit à la Stiglitz and Weiss (1981). Thus, in these theoretical analyses, the introduction of public credit guarantees results in an increase in the availability of loans for previously unfunded projects and may contribute to restoring efficiency in the credit market (Mankiw, 1986; Gale, 1990, 1991). On the other hand, using an alternative model, de Meza and Webb (1987) argue that, under the assumption that investment returns are ranked in terms of first-order stochastic dominance, ${ }^{4}$ asymmetric information will result in an excess supply of credit and yield “too much investment.” In the analytical framework of de Meza and Webb (1987), public credit guarantees will also increase the availability of loans to firms, but exacerbate the problem of

${ }^{3}$ For a detailed account of the SCG program, see Uesugi, Sakai, and Yamashiro (2010).

${ }^{4}$ The theoretical model in Stiglitz and Weiss (1981) assumes second-order stochastic dominance. The contrasting results between Stiglitz and Weiss (1981) and de Meza and Webb (1987) rest on the different assumptions with regard to the risk-return relationship of investment projects. See Freixas and Rochet (2008, p.177) and de Meza (2002). 
over-investment by low-quality borrowers (de Meza, 2002; Innes 1991).

Note that even in theoretical models based on Stiglitz and Weiss (1981), public credit guarantees do not necessarily ensure improvements in the average quality of projects implemented. Hence, whether the public guarantees will improve the ex-post performance of program users is an empirical matter. Moreover, several contractual features of the ECG program may worsen the ex-post performance of borrowers. First, the 100 percent coverage of default costs by the credit guarantee corporation significantly reduces banks' incentives to monitor borrower firms (lender moral hazard). Second, the lack of requirement for collateral in the ECG program may also exacerbate the moral hazard problem on the part of borrower firms by resulting in reduced managerial effort (Boot, Thakor, and Udell, 1991) and/or asset substitution (Stulz and Johnson, 1985). Based on these considerations, our first empirical hypothesis is as follows:

Hypothesis 1 (Effects of Credit Guarantees): Loan availability increases for users of public credit guarantees. In addition, the ex-post performance of firms using credit guarantees improves if increased credit is used for profitable projects with a positive net present value. Alternatively, the ex-post performance of guarantee user firms deteriorates if increased credit exacerbates the over-investment problem and/or results in moral hazard problems.

Previous empirical studies on credit guarantees generally find that credit guarantees have a positive impact on the availability of credit for small businesses (see, e.g., Cowling (2010) for Britain; Riding, Madill, and Haines (2007) for Canada; Uesugi, Sakai, and Yamashiro (2010) for Japan; and Zecchini and Ventura (2009) for Italy). However, the evidence on the ex-post performance of guarantee users is mixed. Riding and Haines (2001), for example, find positive job creation amongst Canadian guarantee program users. They also note that the default rates of program users are particularly sensitive to the coverage ratio of the guarantee program. Using firm level data of Korean credit guarantee user and non-user firms, Kang and Heshmati (2007) and Oh et al. (2009) examine the determinants of guarantee use and the ex-post performance of guarantee users. Although the two studies employ different empirical approaches (Heckman's two-step estimation in the case of the former and propensity score matching estimation in the case of the latter), both find 
that the use of credit guarantees positively affects the growth of sales and reduces the default rate of firms. Oh et al. (2009) suggest that the decline in the default rate may be evidence of credit rationing in the absence of credit guarantee programs. On the other hand, the evidence on employment growth and productivity growth in the two studies is mixed, while both do not find a significant effect on investment. Finally, using Japanese firm level data and employing propensity score matching, Uesugi, Sakai, and Yamashiro (2010) find that firms that participated in the SCG program in the late 1990s tended to experience a decrease in profitability and saw an increase in the probability of financial distress and default.

\subsection{Main Bank Relationships and Effects of Credit Guarantees}

As noted earlier, a number of theoretical and empirical studies have examined whether close firm-bank relationships reduce informational friction between a borrower and a lender and thus improve the availability of credit, especially for smaller and younger firms that are more informationally opaque (e.g., Angelini, Di Salvo, and Ferri, 1998; Cole, 1998; Jiangli, Unal, and Yom, 2008; Petersen and Rajan, 1994). What has not received much attention in the literature, however, is how firm-bank relationships affect the economic effects of public credit guarantee programs.

On the one hand, a relationship lender (a main bank in our analysis) may use the credit guarantee program to supplement its efforts to help borrowers in temporary distress. If that is the case, then it is likely that the guaranteed loans are complimentary to non-guaranteed loans provided by the relationship lender and hence increases not only the availability of guaranteed loans but also the availability of non-guaranteed loans. Moreover, the provision of guaranteed loans through relationship lenders, based on the soft information they have accumulated, is likely to result in the improvement of ex-post performance of borrower firms. Such complementarity between lending relationships and the credit guarantee program may well appear if banks are risk-averse and/or the size of loans is sufficiently large so that banks have an incentive for risk-sharing.

On the other hand, it is also possible that banks may want to substitute guaranteed loans for existing loans (Vogel and Adams, 1997). In this case, close firm-bank relationships may be detrimental for the effectiveness of credit 
guarantees program, because relationship lenders will exploit their informational advantages. Similar to the problem of conflicts of interest for bank underwriting of corporate bonds in which an informed bank underwrites and distributes corporate bonds of low quality firms to outside investors in order to redeem its existing loans, ${ }^{5}$ an informed relationship lender may switch from non-guaranteed loans to guaranteed loans, and thus transfer credit risks of deteriorating firms to the public credit guarantee program. Thus, we would observe a decrease in non-guaranteed loans and a deterioration in the ex-post performance of borrowers that have obtained a guaranteed loan from their relationship lender. These possible effects are summarized in our next hypothesis:

Hypothesis 2 (Main Bank Relationships and the Effects of Credit Guarantees): Credit availability and firms' ex-post performance improve if the main bank uses the guarantee program in order to augment its efforts to support firms in difficulties. Alternatively, credit availability and firms' ex-post performance deteriorate if the main bank exploits its informational advantages to identify low quality firms, substitutes guaranteed loans for non-guaranteed loans, and transfers credit risks to the guarantee program.

Note that the relationship between non-guaranteed loans and guaranteed loans also depends on the institutional features of credit guarantee programs. As discussed in Riding, Madill, and Haines (2007), guarantee programs in the United States are designed to act as lenders of last resort, and are provided only to small businesses that fail to find other sources of financing. Loan guarantee programs in other countries, such as Canada and Britain, allow credit guarantee applicants to have their own non-guaranteed loan balances, but are also explicit in their stated objective that the majority of firms obtaining guaranteed loans should be firms that have been unable to obtain financing from alternative sources. ${ }^{6}$ In these countries, guaranteed loans are almost always substitutes for non-guaranteed loans. Nevertheless, our empirical

\footnotetext{
${ }^{5}$ There are a number of studies that have empirically examined whether the pricing and default performance of corporate bonds underwritten by commercial banks or their affiliates are consistent with the conflict-of-interest hypothesis. See, for instance, Kroszner and Rajan $(1994,1997)$ and Puri $(1996)$ on the pre-Glass-Steagall-Act period in the United States, Gande et al. (1997) on Section 20 subsidiaries during the pre-Gramm-Leach-Bliley-Act period in the United States, and Hamao and Hoshi (2000) and Kang and Liu (2007) on the post-1933 Financial System Reform Act-period in Japan.

${ }^{6}$ This principle is referred to as additionality or incrementality.
} 
hypothesis may shed light on the effectiveness of credit guarantees in these countries as well, because relationship lenders in these countries also have incentives and opportunities to exploit their informational advantages at the expense of public guarantee programs.

\section{Data and Empirical Approach}

\subsection{Data Sources}

The data used in this study are mainly taken from the Kigyo Kinyukikan tono Torihiki Jittai Chosa (Survey on Inter-firm and Firm-Bank Transactions) in February 2008 and the Kinyukikika ni okeru Kigyo Kinyukikan tono Torihiki Jittai Chosa (Survey on Inter-firm and Firm-bank Transactions during the Financial Crisis) in February 2009. ${ }^{7}$ Both surveys were conducted by the Research Institute of Economy, Trade and Industry, a research institution affiliated with the Ministry of Economy, Trade and Industry of Japan, and will be referred to as "RIETI surveys" hereafter. These RIETI surveys asked firms about a variety of issues such as the uses of credit guarantees, the amount of guaranteed loans obtained, the total loan amount outstanding, and their relationships with banks (e.g., the duration of their banking relationships). Further, the 2009 survey included several questions regarding the impact of the financial crisis following the failure of Lehman Brothers in the fall of 2008, including the use of the ECG program.

The 2008 survey questionnaire was sent to 17,018 firms chosen from firms that had responded to previous government surveys compiled by the Small and Medium Enterprise Agency. Firms surveyed were randomly drawn from the database of Tokyo Shoko Research (hereafter TSR database), a business database company. The TSR database covers more than 1.2 million Japanese firms and maintains information on firms' financial statements as well as their primary characteristics, including the firm age, ownership structure of the firm, and the identity of banks they transact with. The number of respondent firms to the 2008 survey is 6,079, for response rate of 35.7 percent. The size distribution of these responding firms compared with that of the original sample is slightly more bunched around the center, i.e., fewer firms are distributed at both tails. The 2009 survey questionnaire was sent to 5,979 firms, those that responded to the 2008

\footnotetext{
${ }^{7}$ A paper summarizing the results of these surveys (Uesugi et al. 2009) is available in Japanese.
} 
survey excluding defaulters. The number of respondent firms in the year is 4,103 , for a response rate of 68.6 percent. Based on these respondent firms to the 2008 and 2009 surveys, we produce a balanced firm-bank matched panel dataset used for our analysis.

The RIETI surveys have a few notable features that are particularly suitable for testing the effectiveness of the credit guarantee programs. First, for each firm, the surveys identify at most two banks (deposit-taking financial institutions) with which firms have the largest and the second-largest amount of loans outstanding. Hence, we are able to concatenate the financial characteristics of these banks that may affect firms' availability of credit. In addition, the surveys also identify the main bank of a firm, and we use the information in order to define which bank is the relationship lender of a firm. 89 percent of firms in our dataset respond that their main bank is the same as the bank with which it has the largest amount of loans outstanding. Second, for each firm-bank match in which a bank is either a main bank or a non-main bank, the 2009 survey identifies the use of ECG loans including the loan amount. In addition, the RIETI surveys identify the amount of total loans outstanding of a particular firm, including both ECG loans and non-ECG loans in the years 2008 and 2009. Hence, we are able to examine not only the amount of ECG loans extended to a firm but also the change between 2008 and 2009 in the amount of non-ECG loans outstanding to the firm. Non-ECG loans consist of regular credit guaranteed loans and non-guaranteed loans, and 39.4 percent of our firm-bank matched observations include loans with regular credit guarantees.

Other than the RIETI surveys, we employ the TSR database where we obtain firms' financial data. Firms whose most recent financial statements in the TSR database are before January 2008 are excluded from our dataset. Next, we employ another set of data sources for the financial status of main and non-main banks. The main source for this information is the Financial QUEST database provided by Nikkei Media Marketing, Inc., with missing data supplemented from the website of the Financial Services Agency, which provides information on regional financial institutions, ${ }^{8}$ and from banks' annual reports. Observations for which we cannot obtain data on banks (e.g., credit cooperatives) are dropped from our dataset.

\footnotetext{
${ }^{8}$ http://www.fsa.go.jp/policy/chusho/shihyou.html
} 
Using these data sources, we construct a firm-bank matched panel dataset with the dependent and independent variables explained in the following subsection. Because of the exclusion of observations explained above, as well as occasional missing answers to the RIETI surveys, ${ }^{9}$ we are left with 2,498 firm-bank matched observations (1,732 firms), with 1,502 for firm-main bank matches and 998 for firm-non-main bank matches. These constitute our dataset for the analysis.

\subsection{Variables}

We have several sets of variables to examine our empirical hypotheses. A list of variables and their definitions are presented in Table 1.

\subsubsection{Availability of Loans and Ex-post Performance}

First, in order to gauge the amount of loans available to a firm, we use several loan variables, controlling for firm size by dividing the loan amount by the firm's total assets in 2008. The first variable is the amount of ECG loans the firm obtained from a particular bank (ECG_LOAN_RATIO), the second is the change between the February 2008 and February 2009 RIETI surveys in the amount of outstanding loans from a particular bank (dB_LOAN_RATIO), and the third is the change between the two surveys in the total amount of the firm's outstanding loans from all financial institutions (dB_TLOAN_RATIO). Because dB_LOAN_RATIO consists of ECG loans and non-ECG loans (regular credit guaranteed loans and non-guaranteed loans), the difference between dB_LOAN_RATIO and ECG_LOAN_RATIO represents the change in the amount of non-ECG loans within a firm-bank match. In contrast, the difference between dB_TLOAN_RATIO and dB_LOAN_RATIO represents the change in the amount of loans from other banks.

Another variable we use, which is somewhat similar to dB_TLOAN_RATIO, is dLOAN_RATIO, the change in total loans from both financial institutions and non-financial institutions (such as parent companies, owners, etc.). The virtue of dLOAN_RATIO is that we can divide it into short-term loans (dSHORT_RATIO) and long-term loans

${ }^{9}$ The most frequently missing variables are the identity of the main bank and non-main banks as well as the firm-bank relationship variables described below. 
(dLONG_RATIO), so that we can make inferences on how the use of ECG loans affects the maturity of a firm's loans outstanding.

Second, we construct a set of variables in order to see how firms allocate ECG loans and how their performance changes. Note that all the variables below are yearly differences between 2008 and 2009, so that we effectively look at changes within the year after ECG loans were extended. Again, variables with "RATIO” are adjusted for firm size using total assets in 2008. To see how ECG loans are allocated, we use dCASHRATIO and dTANGIBLERATIO, which measure changes in the liquidity position and investment activity of a firm, respectively. Proxies for a firm's ex-post performances are dROA (return on assets to measure profitability), dSCORE (the TSR credit score to measure a firm's creditworthiness), and dlnEMP (the number of employees in logarithm to measure a firm's size). The change in ROA can be decomposed into the change in gross sales (dSALESRATIO) and the change in operating costs (dCOSTRATIO). dRATE (interest payments divided by a firm's total assets) is also employed to see whether the use of ECG loans contributes to a decrease in interest payments.

\subsubsection{Determinants of the use of ECG program}

To examine the determinants of the use of the ECG program, we consider four categories of variables: characteristics of credit guarantees, borrower firm characteristics, characteristics of the bank (either a main bank or a non-main bank) that extends ECG or non-ECG loans, and variables describing the relationship between a firm and the bank that extends the ECG or non-ECG loans. Table 2 presents summary statistics of these variables, with the left, center, and right blocks of columns presenting summary statistics for the full-sample of firm-bank matches, for the firm-bank matches where ECG loans are extended, and for the firm-bank matches where non-ECG loans are extended, respectively. Tables 3 and 4 present similar summary statistics for firm-main bank matches and firm-non-main bank matches, respectively.

The dependent variable, ECG_DUM, is a dummy variable that equals one if a borrower firm obtained ECG loans between October 31, 2008 (the onset of ECG Program) and February 2009 (when the 2009 RIETI survey was 
conducted). In about 15 percent of firm-bank matches in our entire sample, the ECG program was used during this period (Table 2). Tables 3 and 4 indicate that the ratio is substantially higher for firm-main bank matches (21.2 percent) than for firm-non-main bank matches (4.7 percent), indicating that ECG loans are more likely to be provided by main banks.

As noted above, we consider four categories of independent variables: characteristics of credit guarantees, firm characteristics, bank characteristics, and bank-firm relationships. Firm and bank characteristics variables are as of 2008 (one year prior to the 2009 RIETI survey), whereas bank-firm relationship variables are as of February 2009. A few things are worth mentioning.

First, in 39.4 percent of firm-bank matches in our entire sample, regular credit guarantee (RCG) loans were used at the time of the 2009 RIETI survey. Among ECG loan users, the ratio of firms that have also obtained regular credit guarantees program loans (RCG_DUM) is 76.2 percent, implying that ECG loans are used supplementary to regular program loans. Second, regarding firm characteristics, we find that the profitability (SHARPERATIO) and creditworthiness (SCORE) of ECG loan users are lower on average than those of non-ECG loan users, and the difference in these variables between the two groups (e.g., $\mathrm{SCORE}_{\mathrm{ECG} \_\mathrm{DUM}=1}-\mathrm{SCORE}_{\mathrm{ECG} \_\mathrm{DUM}=0}$ ) is greater for firm-main bank matches than for firm-non-main bank matches. That is, the relative performance of ECG loan user is worse if the firm obtains the ECG loan from its main bank.

Third, the mean values of the regional bank dummy B_REGIONAL indicate that ECG loans are more likely to be provided by regional banks, especially when the regional bank is the main bank of a firm. Table 3 shows that, within the subsample of firm-main bank matches, 87.4 percent of ECG loan are extended by regional banks, whereas the ratio is 70.9 percent for non-ECG loans. Fourth, other variables on bank characteristics include the Herfindahl index calculated for each prefecture (HHI) and the bank's share of branches within the prefecture of a borrowing firm (BANKSHARE). The former variable represents the degree of competition among banks in each prefecture, while the latter proxies the bargaining power of a bank vis-à-vis a credit guarantee corporation in a particular prefecture. Table 2 shows that the values for HHI are quite similar between firm-bank matches with ECG loans and those with non-ECG loans, 0.113 and 
0.106, respectively. On the other hand, the table shows a positive association between BANKSHARE and the use of ECG loans, that is, the higher the share a bank has in the local loan market, the more frequently the bank extends ECG loans.

Lastly, the dummy variable LOAN_ENQUIRY represents whether a firm requested a loan within the year, and we treat this variable as a proxy for loan demand. For firm-main bank matches (Table 3), the mean value of LOAN_ENQUIRY is higher for ECG loan user firms (0.506) than that for non-users $(0.368)$, indicating that the use of the ECG program is positively associated with the strength of firms' loan demand. In contrast, for firm-non-main bank matches (Table 4), the use of the ECG program is negatively associated with LOAN_ENQUIRY (0.170 for ECG loan users and 0.292 for non-users). This suggests that in these instances, firms obtain ECG loans as a result of solicitations from non-main banks rather than enquiries of their own accord.

\subsection{Empirical Approach}

Using the dataset just described, we proceed to examine the economic effects of the ECG program. Note, however, that a simple comparison of the availability of loans for, and ex-post performance of, ECG program users and non-users is not appropriate because of possible selection bias. For example, if firms that obtain ECG loans are ex-ante observably riskier than those not using the ECG program, then a simple comparison between the two groups confounds ex-ante riskiness and ex-post riskiness (changes in borrowers' riskiness after the loan is extended). To circumvent this problem, we need to control for any possible selection bias in our estimation. To do so, we employ the matching estimation approach. The procedure is as follows:

(i) We implement a probit estimation that models the probability of firms' using the ECG program between October 31, 2008, and February 2009 conditional on firm characteristics, bank characteristics, and bank-firm relationships. Borrowers that obtain ECG loans (ECG_DUM=1) are labeled treatment observations. We then attach a propensity score to each observation. The propensity score is defined as

$$
e\left(X_{t}\right) \equiv \operatorname{Pr}\left(E C G_{-} D U M_{t}=1 \mid X_{t-1}\right)
$$


where $X_{t-1}$ is a vector of covariates in the probit estimation.

(ii) Next, for each treatment observation, we identify matched observations from the sample of non-ECG users. The matched observations are those that have the "closest" propensity scores to a particular treatment observation and are labeled control observations. It should be noted that we may use non-treated observations more than once as a control observation, that is, a non-treatment observation may be used as a control observation for one treatment observation and as a control observation for another treatment observation at the same time. There are several matching algorithms to find the "closest" control observations. As a baseline for our analysis, we employ kernel matching.

(iii) Finally, we compare the change (difference between 2009 and 2008) in the loan availability and ex-post performance variables of the treatment and the control group as described in the previous subsection. To be precise, for ex-post performance variables, we use the difference-in-difference (DID) estimator defined as $\Delta Y_{t+1}^{T, i}-\Delta Y_{t+1}^{C, i}$, where $Y$ indicates the loan availability variable, $t$ is the year in which firms decide whether to use the ECG program, and superscripts $T, i$ and $C$, $i$ stand for the treatment firm $i$ and its control group firms, respectively.

With respect to loan availability variables, we measure the changes from year $t-1$ to $t$, because we would like to know the contemporaneous effects of an ECG loan to a firm on non-ECG loans from the same bank and non-ECG loans from other banks.

One of the benefits of employing propensity score matching estimation is that we can match treatment and control observations using the scalar propensity score. The propensity score, which is the conditional probability of being treated given the value of observed characteristics, is a very useful variable in dealing with a highly dimensional vector of covariates. Rosenbaum and Rubin (1983) showed that treatment observations (in our case firms that obtain ECG loans) and control observations (those that obtain non-ECG loans) with the same propensity score value have the same distribution of the full vector of covariates. It is thus sufficient to match firms in terms of the propensity score in order to obtain the same probability distribution of covariates for treatment and control observations.

In propensity score matching, an assumption known as unconfoundedness has to be satisfied so that the differences in ex-post performance variables between the treated observations and the control observations with the same 
propensity scores are attributable to the treatment effect of using the ECG program (Rosenbaum and Rubin, 1983). That is,

$$
\left(\Delta Y_{t+1}^{T}, \Delta Y_{t+1}^{C}\right) \perp E C G_{-} D U M_{t} \mid e\left(X_{t-1}\right)
$$

needs to hold. Although there is no direct test for unconfoundedness, this assumption means that it is necessary to control for all relevant variables $X_{t-1}$ that influence the selection of treatment observations and their ex-post performance variables. We believe that our data is rich enough to include all the necessary covariates. Furthermore, the DID matching estimator that we use allows for the existence of differences in time-invariant unobservable characteristics between the treatment and the control group.

\section{Results}

We use a probit model in order to estimate a propensity score for each firm-bank match observation in Section 5.1, followed by the treatment effect estimation in Section 5.2. Further, in Section 5.3, we explicitly focus on the quantitative impact of the ECG program in terms of the increase in firms’ total loans from banks. Specifically, using OLS regression, we examine by how many percentage points the total loan ratio increases as a result of a one percentage point increase in the ECG loan ratio.

\subsection{Probit model estimation}

We start our estimation procedure with the probit model equation, as specified in equation (1):

$\operatorname{Pr}\left(E C G_{i j t}=1 \mid X_{i j t-1}\right)=\Psi\left(\beta_{0}+\beta_{1}\right.$ CreditGuarantees $_{i j t}+\beta_{2}$ Firm $_{i t-1}+\beta_{3}$ Bank $_{j t-1}$

$+\beta_{4}$ Relationship $_{\mathrm{ijt}}$ )

We have two groups of firm-bank matched observations: firm-main bank matches and firm-non-main bank matches. There may well be different coefficients between these two groups. We first divide the entire set of observations into 
these two groups and estimate equation (1) for each of them. Then we conduct our estimation for the entire sample.

The estimation results are presented in Table 5. The left, center, and right blocks represent the parameters for the sample of firm-main bank matches, the sample of firm-non-main bank matches, and the sample of all firm-bank matches, respectively. For the firm-main bank matched sample, the coefficient on RCG_DUM is significantly positive, indicating that the use of Emergency Credit Guarantees and the use of regular credit guarantees are complementary.

As for firm characteristics, the coefficients on SCORE and CAPRATIO_NG are negative and significant. This indicates that firms with a low creditworthiness are more likely to use the ECG program, but are less likely to obtain ECG loans once they become distressed to the point that their capital ratio is negative, presumably because of the relatively stringent lending standards under the ECG program. In contrast, the profitability of firms (SHARPERATIO) does not have a significant effect on the use of the ECG program. The coefficient on LOANRATIO is significantly positive and that on InSALES significantly negative, while that on InFIRMAGE is insignificant. That is, firms with a greater reliance on debt-financing and smaller firms are more likely to use the program. A firm's demand for loans, as proxied by LOAN_ENQUIRY, has a significant positive effect on the use of the ECG program.

Turning to bank characteristics in the firm-main bank matched sample, the capital-asset ratio based on the Basel Capital Accord has different impacts on the use of Emergency Credit Guarantees depending on the type of the bank each firm transacts with. If it is a regional bank, the impact of the bank's capital-asset ratio (the sum of the coefficients on B_REGIONAL*BIS and BIS) is not significant on the use of the program. In contrast, if it is a city bank or other large bank, use of the program is negatively associated with its capital-asset ratio. The difference between city banks and regional banks implies that the former, most of which need to abide by the more stringent capital requirements applied to banks operating internationally, face greater pressure to have a larger capital buffer. Hence, city banks are more likely to provide ECG loans whose risk weight (0 percent) is smaller than that of non-ECG loans. The coefficient on $\mathrm{HHI}$ is negative and weakly significant, indicating that firms located in a prefecture with fiercer competition among banks are more likely to obtain ECG loans. In contrast, the coefficient on BANKSHARE is positive, but insignificant.

It is worth comparing the above results with those for the firm-non-main bank matched sample. As in the 
estimation for the firm-main bank matched sample, the coefficients on RCG_DUM and LOANRATIO are positive and significant. Moreover, the coefficients on the variables for bank characteristics have the same sign. Turning to firm characteristics, the coefficient on CAPRATIO_NG is also negative for the firm-non-main bank sample, but it is significant only at the 10 percent level. On the other hand, SCORE and InSALES become insignificant, meaning that unlike firms that obtain ECG loans from their main bank, firms that obtain ECG loans from non-main banks are neither riskier nor smaller than the sample population. Further, the coefficient on LOAN_ENQUIRY turns significantly negative, indicating that firms not actively seeking a loan were likely to be solicited by non-main banks to use the ECG program.

Finally, we conduct the probit model estimation for the entire sample. We introduce an interaction term between B_MAIN and LOAN_ENQUIRY, since the effect of borrowers' loan demand on the use of ECG loans differs between the two subsamples. Consistent with the summary statistics, ECG loans are more likely to be extended by the main bank, as indicated by coefficients on B_MAIN and B_MAIN*ENQUIRY. The results for the other variables appear to be more in line with the results for firm-main bank matched observations than those for firm-non-main bank matches. In addition, some of the variables which are insignificant or only marginally significant in the subsample estimations become significant due to smaller standard errors. Specifically, this is the case for BANKSHARE and HHI. In the next subsection, we use the estimation results for the entire sample in order to calculate propensity scores and then implement the treatment effect estimation.

\subsection{Treatment effect estimation}

Based on the propensity scores obtained from the probit model regression for the entire sample in the previous subsection, we estimate the treatment effect of the ECG program using kernel matching estimators. We match each treated observation with the non-treated observations, each of which has its own weight that is proportional to the "closeness" to the treated observation. Here, closeness is measured by the propensity scores of treated and non-treated observations. Note that we omit non-treated observations of the same firm receiving an ECG loan from another bank from the entire sample. We do this in order to avoid that the same firm appears both in the treatment and control groups. 
The estimation results for the treatment effect are reported in Table 6. Panel (a) shows the result for the entire sample, which we consider as the baseline case. Panels (b) and (c) present the results for the subsamples of firm-main bank matches and firm-non-main bank matches, respectively. For each of the variables, there is an unmatched estimator and an ATT (average treatment effect on the treated) estimator, both of which are shown in the column labeled "Difference."

For example, in the "Unmatched" row for the variable dB_LOAN_RATIO in Panel (a), there are two values, one for the treatment group (in this case, firm-bank matches with ECG loans) and one for the non-treatment group (firm-bank matches without ECG loans), which are 0.050 and 0.008 , respectively. The former value indicates that, between 2008 and 2009, an ECG user's borrowing from a bank on average increased by an amount equivalent to 5.0 percent of the firm's total assets, while the latter indicates that a non-ECG user’s borrowing from a bank during the same period increased by an amount equivalent to 0.8 percent of its total assets. The difference between these two figures, 4.2 percentage points, shown in the column labeled "Difference," is the unmatched estimate of the treatment effect. Note, however, that the unmatched estimate may well be biased since ex-ante differences in terms of firm characteristics between ECG users and non-users possibly affect the differences in ex-post firm performance. By contrast, the average treatment effect on the treated (ATT) estimator resolves the bias caused by the sample selection. In "ATT” row, the value for the non-treatment group in the "Unmatched" row is replaced by the value for the control group, in which firms are non-ECG users but similar to the ECG users in their characteristics. The difference between the value in the treatment and that in the control, which is equivalent to 5.0 percent of a firm's total assets, is what we aim to obtain as the treatment effect incurred by the use of the ECG program.

We start from the baseline case in panel (a) of Table 6. For the loan availability variables, we observe significant improvements in most of the variables. Not only changes in loans from a bank (dB_LOAN_RATIO), but also changes in a firm's total loans outstanding from banks (dB_TLOAN_RATIO) and changes in a firm's total loans outstanding (dLOAN_RATIO) show significant positive treatment effects. Looking at the components of dLOAN_RATIO, changes in a firm's long-term loans outstanding (dLONG_RATIO) show a significant positive 
treatment effect, while the effect on changes in a firm's short-term loans outstanding (dSHORT_RATIO) is insignificant, suggesting that most of the ECG loans are long-term. The size of ECG loans, which is measured by the treatment effect for the variable ECG_LOAN_RATIO, on average is equivalent to 10.3 percent of a firm's total assets. The increase is partially reflected in the treatment effect on dB_LOAN_RATIO, which sums up the changes in both ECG loans and non-ECG loans extended by the same bank and on average is equivalent to 5.0 percent of a firm's total assets. Also, much of the positive impact on dB_LOAN_RATIO is reflected in the increase of total loans provided by all banks (dB_TLOAN_RATIO) and by all creditors (dLOAN_RATIO). The above results indicate the following. First, banks that extend ECG loans partially offset this by decreasing the amount of non-ECG loans, resulting in an increase in the amount of loans outstanding that is about half the size of the amount of ECG loans. Second, other banks and creditors only slightly offset the increase in the amount of loans provided by banks that extend ECG loans. Overall, these results are consistent with the first part of Hypothesis 1 which stated that loan availability increases for users of public credit guarantees.

Regarding the allocation of funds by program users, no significant treatment effects on dTANGIBLERATIO, dlnEMP, and dCASHRATIO are observed; that is, the increase in loans outstanding results in no significant changes in program users' capital investment behavior, employment, or cash holdings. As for the performance of program users, many of the variables indicate a significant decline. Specifically, these are dSCORE, dSALESRATIO, and dCOSTRATIO. In contrast, there is no significant impact on dROA. Since the time window used for the treatment effect estimation here is only one year, we do not know whether the significant decline in performance among ECG users is only a temporary or a more lasting phenomenon. However, it is worth highlighting that the ex-post decline among ECG users in the amount of sales (equivalent to 12.9 percent of the total amount of assets) and in costs (11.4 percent of the total amount of assets) is quite sizeable. These results are inconsistent with some theoretical models that suggest that public credit guarantees will lead to additional investment in projects with a positive net present value and thereby increase economic efficiency.

Next, panel (b) of Table 6 indicates that much of the "loan substitution" between ECG loans and non-ECG 
loans by the same bank and the deterioration in the ex-post performance of ECG program users are attributable to firms that obtain ECG loans from their main bank. The signs as well as the size of the treatment effects in this panel are quite similar to those in panel (a). In addition, dCASHRATIO becomes marginally positive. This indicates that ECG program users tend to hold cash reserves rather than to invest in tangible or intangible assets. Overall, the results are consistent with the latter part of Hypothesis 2, that is, main banks misuse the ECG program to transfer the credit risk of existing low-quality borrowers to the credit guarantee program.

Finally, panel (c) examines the effects for firm-non-main bank matched observations. There are significant differences from the results in the previous panels. First, even though non-main banks that extended ECG loans partially offset the increase by reducing the amount of non-ECG loans, the extent of such offsetting behavior appears to be relatively small. The difference between ECG_LOAN_RATIO and dB_LOAN_RATIO in the firm-non-main bank matched sample is $0.019(=0.072-0.053)$, while the difference in the firm-main bank matched sample is 0.057 $(=0.107-0.050)$

Second, treatment effects become insignificant or only marginally significant for dB_TLOAN_RATIO and dLOAN_RATIO. These results indicate that other banks appear to withdraw their non-ECG loans, which cancels out the positive treatment effects for ECG_LOAN_RATIO and dB_LOAN_RATIO. However, it would be hasty to conclude that the result contradicts the first part of Hypothesis 1, which is that public credit guarantees are expected to increase credit availability. The probit estimations in Table 5 indicate that the effect of LOAN_ENQUIRY on the use of ECG loans is negative among firms that obtain ECG loans from non-main banks. That is, firms that receive ECG loans from non-main banks may want to reduce their total loan balances since they have no need to procure additional funds. Part of the reason that we do not observe any significant treatment effects on the allocation of funds may be that there is strong demand for repaying non-ECG loans among the ECG users in this subsample. Neither do we observe significant treatment effects among ECG users with regard to the performance variables. This insignificant impact on performance variables can be explained by the demand for repaying previous loans among the ECG users in this subsample rather than the demand for capital investments. 


\subsection{OLS regression for the relationship between ECG loans and firms' loan availability}

In the previous subsection, we argued that the loan "substitution" effects between ECG loans and non-ECG loans are more sizable in the firm-main bank matched sample. In order to reexamine the issue, we employ OLS estimation to gauge the impact of ECG_LOAN_RATIO (explanatory variable) on dB_LOAN_RATIO and dB_TLOAN_RATIO (dependent variables). We use the same set of other explanatory variables as in the probit estimation.

Table 7 presents the results, with panel (a) showing those for the subsample of firm-main bank matched observations and panel (b) showing those for firm-non-main bank matched observations. We focus on the coefficients on ECG_LOAN_RATIO. In the estimation with dB_LOAN_RATIO as the dependent variable, the coefficient on ECG_LOAN_RATIO in panel (a) is 0.444, while in panel (b) the coefficient is 0.905 . That is, an ECG loan amount equivalent to one percent of a firm's total assets provided by a main bank resulted in an increase in total loans extended by the same main bank equivalent to 0.4 percent of the firm's total assets. In contrast, an ECG loan equivalent to one percent of a firm's total assets provided by a non-main bank resulted in a much larger increase in total loans extended by the same non-main bank, namely by an amount equivalent to 0.9 percent of the firm's total assets. For the sample of main bank matches, we can reject that the coefficient is significantly different from unity, while we cannot reject it for the sample of non-main bank matches (results not reported). These results are consistent with those obtained in the previous subsection, which showed that main banks reduced non-ECG loans to offset ECG loans more than non-main banks. This finding is consistent with the latter part of Hypothesis 2, which stated that the main bank exploits its informational advantage to identify low quality firms, substitutes guaranteed loans for non-guaranteed loans, and transfers the firms' credit risks to the guarantee program. In contrast, in the estimation with dB_TLOAN_RATIO as the dependent variable, the coefficient in the firm-main bank matched sample $(0.256)$ becomes actually larger than that in the firm-non-main bank matched sample (0.026 and insignificant). The results for the main bank matches are consistent with the first part of Hypothesis 1 in that loan availability increases for users of public credit guarantees, while this is not 
necessarily the case for the non-main bank matches. Note, however, that the results for the non-main bank matches are consistent with the results obtained in the previous subsection that firms that receive ECG loans from non-main banks may have strong demand to repay previous non-ECG loans.

\section{Conclusion}

This study empirically examined whether the Emergency Credit Guarantee Program introduced by the Japanese government in 2008 increased the availability of bank loans to small businesses and contributed to improving firm performance. Since these firms have limited access to other financing options such as commercial paper, corporate bonds, or equities, the issue is critical for small business financing. The importance of better credit availability is even greater in the context of the current financial crisis. Even though the credit crunch for firms is less severe in Japan than in the United States and Europe, the introduction of a massive credit guarantee scheme may have helped to ease financing conditions for small businesses.

Our empirical findings confirm that the ECG program is generally effective in improving firms' access to credit. However, we did not find firm evidence that incremental funds supplied by the ECG program help to boost investment by, or employment at, user firms. Nor do we find evidence that, in the one-year window that our data cover, the program improved the ex-post profitability or creditworthiness of ECG program users. On the contrary, we find a significantly negative impact of the ECG program on user firms' creditworthiness as indicated by the decline in the TSR credit score. Although we cannot make solid inferences from observations spanning only a one-year period, our results are consistent with the moral hazard hypothesis regarding the effect of credit guarantees.

We also find evidence that the determinants of the use of the ECG program and its economic impact differ depending on the extent of firm-bank relationships. In particular, we find that a relationship lender (main bank) is more likely to extend ECG loans to observably riskier firms and to offset partially, if not completely, the increase in ECG loans by a decrease in non-ECG loans. We do not find such a loan "substitution" effect when the ECG loans were extended by non-main banks. In addition, our treatment effect estimations based on the propensity score matching methodology find a 
deterioration of TSR credit scores only in the firm-main bank matched subsample. Taken together, these findings suggest that main banks exploit their informational advantage with regard to their borrowers and use the ECG program to transfer credit risks of low quality firms to the guarantee program.

The Emergency Credit Guarantee Program, with its 100 percent credit guarantee, is scheduled to expire in March 2011 and will be replaced by the regular program, which provides a guarantee coverage of only 80 percent. Reducing the guarantee coverage represents a first [important] step in restraining banks, especially main banks that have informational advantage, from substituting credit guaranteed loans for non-guaranteed loans. Additionally, our findings have some policy implications for the institutional architecture of credit guarantee programs. In the literature on small business financing, a stable relationship between a firm and a bank is generally regarded to be beneficial in improving access to credit when a firm is in temporary distress. However, when combined with a credit guarantee program, close firm-bank relationships may have perverse effects as the credit guarantees may distort banks' incentives. That is, a bank that has proprietary information on firms may exploit its advantage and extend guaranteed loans to substitute for its non-guaranteed loans to risky firms.

In order to circumvent such misuse of the program by a relationship lender, several institutional changes may be worth considering. One potential measure to discipline financial institutions would be to introduce a program that differentiates lenders based on the ex-post performance of their guaranteed loans (for instance, the ex-post default rate of guaranteed loans). Such a scheme can, for instance, be found in the Certified and Preferred Lenders Program of the Small Business Administration of the United States. Limiting firms eligible for a credit guarantee program to those that have not established a stable relationship with a bank (e.g., newly established firms) would be an alternative way to prevent the abuse of the program. By excluding firms that have established close relationships with banks from the group of eligible firms for credit guarantees, it would be possible to prevent the kind of opportunistic behavior by banks that the findings of this paper suggest. 


\section{References}

Angelini, P., Di Salvo, R., and Ferri, G., 1998, “Availability and Cost of Credit for Small Businesses: Customer Relationships and Credit Cooperatives,” Journal of Banking and Finance 22, 925-954.

Boot, A., Thakor A., and Udell G., 1991, “Secured Lending and Default Risk: Equilibrium Analysis, Policy Implications and Empirical Results,” Economic Journal 101, 458-472.

Cole, R. A., 1998, “The Importance of Relationships to the Availability of Credit,” Journal of Banking and Finance 22, 959-977.

Cowling, M., 2010, “The Role of Loan Guarantee Schemes in Alleviating Credit Rationing in the UK," Journal of Financial Stability 6, 36-44.

de Meza, D., 2002, “Overlending?” Economic Journal 112, F17-F31.

de Meza, D. and Webb, D. C., 1987, “Too Much Investment: A Problem of Asymmetric Information,” The Quarterly Journal of Economics 102, 281-292.

Gale, W. G., 1990, “Federal Lending and the Market for Credit,” Journal of Public Economics 42, 177-193.

Gale, W. G., 1991, “Economic Effects of Federal Credit Programs,” American Economic Review 81, 133-152.

Gande, A., Puri, M., Saunders, A., and Walters, I., 1997, "Bank Underwriting of Debt Securities: Modern Evidence," Review of Financial Studies 10, 1175-1202.

Hamao, Y, and Hoshi, T., 2000, "Bank Underwriting of Corporate Bonds: Evidence from Japan After the Financial System Reform of 1993,” Mimeo, April.

Innes, R., 1991, "Investment and Government Intervention in Credit Markets When There is Asymmetric Information," Journal of Public Economics 46, 347-381.

Jiangli, W., Unal, H., and Yom, C., 2008, "Relationship Lending, Accounting Disclosure, and Credit Availability During the Asian Financial Crisis,” Journal of Money, Credit, and Banking 40(1), 26-55.

Kang, J. W., and Heshmati, A., 2008, "Effect of Credit Guarantee Policy on Survival and Performance of SMEs in Republic of Korea,” Small Business Economics 31, 445-462.

Kang, J., and Liu, W., 2007, "Is Universal Banking Justified? Evidence from Bank Underwriting of Corporate Bonds in Japan,” Journal of Financial Economics 84, 142-186.

Kroszner, R. S., and Rajan, R. G., 1994, "Is the Glass-Steagall Act Justified? A Study of the U. S. Experience with Universal Banking Before 1933,” American Economic Review 84, 810-832. 
Kroszner, R. S., and Rajan, R. G., 1997, “Organization Structure and Credibility: Evidence from Commercial Bank Securities Activities before the Glass-Steagall Act,” Journal of Monetary Economics 39, 475-516.

Mankiw, G. N., 1986, “The Allocation of Credit and Financial Collapse,” Quarterly Journal of Economics 101, 455-470.

OECD, 2009, "The Impact of the Global Crisis on SME and Entrepreneurship Financing and Policy Responses,” A report prepared by a team of the SME and Entrepreneurship Division of the OECD Center for Entrepreneurship, SMEs and Local Development, together with Lorraine Ruffing.

Oh, I., Lee, J., Heshmati, A., and Choi, G., 2009, "Evaluation of Credit Guarantee Policy Using Propensity Score Matching,” Small Business Economics 33, 335-351.

Petersen, M. A., and Rajan, R. G., 1994, “The Benefits of Lending Relationships: Evidence from Small Business Data," Journal of Finance 49, 3-37.

Puri, M., 1996, “Commercial Banks in Investment Banking: Conflict of Interest of Certification Role?” Journal of Financial Economics 40, 373-401.

Riding, A. L., and Haines, G. Jr., 2001, "Loan Guarantees: Costs of Default and Benefits to Small Firms,” Journal of Business Venturing 16, 595-612.

Riding, A., Madill, J., and Haines, G. Jr., 2006, “Incrementality of SME Loan Guarantees,” Small Business Economics 29, 47-61.

Rosenbaum, P. and Rubin, D., 1983, "The Central Role of the Propensity Score in Observational Studies for Causal Effects,” Biometrika 70, 41-55.

Stiglitz, J., and Weiss, A., 1981 “Credit Rationing in Markets with Imperfect Information,” American Economic Review 71, 93-410.

Stulz, R., Johnson, H., 1985, “An Analysis of Secured Debt,” Journal of Financial Economics 14, 501-521.

Uesugi, I., Sakai K., and Yamashiro, G. M, 2010, “The Effectiveness of the Public Credit Guarantees in the Japanese Loan Market,” Journal of the Japanese and International Economies 24, 457-480.

Vogel, R. C. and Adams, D. W., 1997, “Costs and Benefits of Loan Guarantee Programs,” The Financier 4, 22-29.

Zecchini, S. and Ventura, M., 2009, “The Impact of Public Guarantees on Credit to SMEs,” Small Business Economics 32, 191-206. 
Table 1: Definitions of variables

(a) Outcome variables

\section{Loan availability}

ECG_LOAN_RATIO

dB_LOAN_RATIO

= ECG loans respondent firm obtained from a particular bank / firm's assets

dB_TLOAN_RATIO

= change in loans outstanding from a particular bank / firm's assets

dLOAN_RATIO

= change in firm's total outstanding loans from all banks / firm's assets

= change in firm's total loans outstanding / firm's assets, consisting of short-term loans and

bills discounted (dSHORT_RATIO) and long-term loans (dLONG_RATIO)

\section{Ex-post firm performance}

$\begin{array}{ll}\text { dCASHRATIO } & =\text { change in cash and deposits / firm's assets } \\ \text { dTANGIBLERATIO } & =\text { change in tangible assets / firm's assets } \\ \text { dROA } & =\text { change in ROA (operating profits / firm's assets), which equals dSALESRATIO (change } \\ & \text { in gross sales ratio) minus } d \text { COSTRATIO (change in operating costs ratio) } \\ \text { dSCORE } & =\text { change in TSR credit score (1-100 points) } \\ \text { dInEMP } & =\text { change in number of employees in logarithm } \\ d R A T E & =\text { change in interest payments / firm's total loans outstanding }\end{array}$

\section{(b) Determinant variables}

\section{Characteristics of credit guarantees}

ECG_DUM

RCG_DUM

LOAN_ENQUIRY

SHARPERATIO

SCORE

CAPRATIO_NG

LOANRATIO

LN_SALES

LN_FIRMAGE

IND1-IND9

\section{Bank characteristics}

B_REGIONAL

BIS

BANKSHARE

HHI
Firm characteristics

1 if firm obtained an ECG loan from a bank, 0 otherwise

1 if firm obtained a regular credit guarantee program loan from a bank, 0 otherwise

1 if firm asked a bank to extend a loan within a year, 0 otherwise

Sharpe ratio: ROA / Std. deviation of ROA, where ROA=operating profits / total assets. The standard deviation of ROA is calculated for years available in the TSR database which dates back from 2007 to as old as 1982.

TSR credit score (1-100 points; a higher score indicates greater creditworthiness)

1 if firm's capital-asset ratio is negative (firm has negative net worth), 0 otherwise

Firm's total loans outstanding / total assets

Log of gross annual sales

Log of firm age

Industry dummies: (1) construction, (2) manufacturing, (3) communication and information, (4) transportation, (5) wholesale, (6) retail, (7) real estate, (8) services, and (9) other

1 if a bank is either a regional bank, a second regional bank, or a Shinkin bank, 0 otherwise Capital asset ratio based on Basel capital framework

Bank's share of branches within the prefecture of a borrowing firm

Herfindahl Index computed based on the shares of bank branches within a prefecture of a borrowing firm

\section{Characteristics of bank-firm relationships}

B_MAIN

1 if a bank is a main bank, 0 otherwise

B_CONTACT
Index variable indicating the frequency of meetings between a borrower firm and a bank: (1) daily, (2) weekly, (3) several times in a week, (4) monthly, (5) once in 2-3 months, (6) semi-annually, (7) annually, (8) less than annually, 9: no direct meetings 


\section{Table 2: Summary statistics: ECG users and non-ECG users}

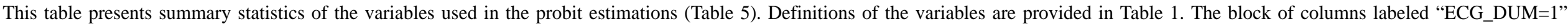

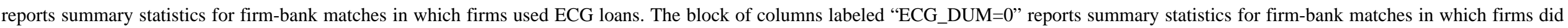
not use ECG loans.

\begin{tabular}{|c|c|c|c|c|c|c|c|c|c|c|c|c|c|c|}
\hline \multirow[b]{2}{*}{ Entire sample } & \multicolumn{6}{|c|}{ All } & \multicolumn{4}{|c|}{ ECG_DUM=1 } & \multicolumn{4}{|c|}{ 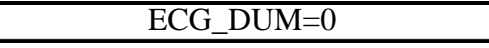 } \\
\hline & $\mathrm{N}$ & mean & sd & $\min$ & p50 & $\max$ & $\mathrm{N}$ & mean & sd & $\mathrm{p} 50$ & $\mathrm{~N}$ & mean & sd & $\mathrm{p} 50$ \\
\hline \multicolumn{15}{|l|}{ Characteristics of credit guarantees } \\
\hline ECG_DUM & 2498 & 0.146 & 0.353 & 0 & 0 & 1 & 365 & 1.000 & 0.000 & 1 & 2133 & 0.000 & 0.000 & 0 \\
\hline RCG_DUM & 2498 & 0.394 & 0.489 & 0 & 0 & 1 & 365 & 0.762 & 0.427 & 1 & 2133 & 0.331 & 0.471 & 0 \\
\hline \multicolumn{15}{|l|}{ Firm characteristics } \\
\hline LOAN_ENQUIRY & 2498 & 0.353 & 0.478 & 0 & 0 & 1 & 365 & 0.463 & 0.499 & 0 & 2133 & 0.334 & 0.472 & 0 \\
\hline SHARPERATIO & 2498 & 0.077 & 1.030 & -10.032 & 0.079 & 6.117 & 365 & -0.170 & 0.922 & -0.164 & 2133 & 0.119 & 1.041 & 0.127 \\
\hline SCORE & 2498 & 55.251 & 6.521 & 27 & 54 & 87 & 365 & 51.397 & 4.445 & 51 & 2133 & 55.910 & 6.592 & 55 \\
\hline CAPRATIO_NG & 2498 & 0.048 & 0.214 & 0 & 0 & 1 & 365 & 0.079 & 0.271 & 0 & 2133 & 0.043 & 0.202 & 0 \\
\hline LOANRATIO & 2498 & 0.393 & 0.266 & 0.000 & 0.360 & 3.639 & 365 & 0.547 & 0.241 & 0.548 & 2133 & 0.366 & 0.261 & 0.326 \\
\hline $\operatorname{lnSALES}$ & 2498 & 7.484 & 1.652 & 0.000 & 7.333 & 14.352 & 365 & 6.723 & 1.214 & 6.653 & 2133 & 7.615 & 1.682 & 7.474 \\
\hline lnFIRMAGE & 2498 & 3.637 & 0.516 & 1.946 & 3.761 & 4.787 & 365 & 3.536 & 0.524 & 3.638 & 2133 & 3.655 & 0.512 & 3.784 \\
\hline IND1 & 2498 & 0.235 & 0.424 & 0 & 0 & 1 & 365 & 0.315 & 0.465 & 0 & 2133 & 0.221 & 0.415 & 0 \\
\hline IND2 & 2498 & 0.257 & 0.437 & 0 & 0 & 1 & 365 & 0.238 & 0.427 & 0 & 2133 & 0.260 & 0.439 & 0 \\
\hline IND3 & 2498 & 0.032 & 0.177 & 0 & 0 & 1 & 365 & 0.022 & 0.147 & 0 & 2133 & 0.034 & 0.182 & 0 \\
\hline IND4 & 2498 & 0.037 & 0.188 & 0 & 0 & 1 & 365 & 0.030 & 0.171 & 0 & 2133 & 0.038 & 0.191 & 0 \\
\hline IND5 & 2498 & 0.227 & 0.419 & 0 & 0 & 1 & 365 & 0.195 & 0.396 & 0 & 2133 & 0.233 & 0.423 & 0 \\
\hline IND6 & 2498 & 0.097 & 0.296 & 0 & 0 & 1 & 365 & 0.101 & 0.302 & 0 & 2133 & 0.096 & 0.295 & 0 \\
\hline IND7 & 2498 & 0.020 & 0.140 & 0 & 0 & 1 & 365 & 0.019 & 0.137 & 0 & 2133 & 0.020 & 0.141 & 0 \\
\hline IND8 & 2498 & 0.004 & 0.066 & 0 & 0 & 1 & 365 & 0.003 & 0.052 & 0 & 2133 & 0.005 & 0.068 & 0 \\
\hline IND9 & 2498 & 0.091 & 0.287 & 0 & 0 & 1 & 365 & 0.077 & 0.266 & 0 & 2133 & 0.093 & 0.291 & 0 \\
\hline \multicolumn{15}{|l|}{ Bank characteristics } \\
\hline B_REGIONAL & 2498 & 0.716 & 0.451 & 0 & 1 & 1 & 365 & 0.847 & 0.361 & 1 & 2133 & 0.693 & 0.461 & 1 \\
\hline B_REGIONAL*BIS & 2498 & 7.801 & 5.913 & -11.570 & 10.050 & 35.300 & 365 & 9.369 & 4.962 & 10.210 & 2133 & 7.533 & 6.021 & 9.910 \\
\hline BIS & 2498 & 11.113 & 3.344 & -11.570 & 11.410 & 35.300 & 365 & 11.070 & 2.974 & 10.750 & 2133 & 11.120 & 3.403 & 11.440 \\
\hline BANKSHARE & 2498 & 0.136 & 0.114 & 0.000 & 0.111 & 0.462 & 365 & 0.160 & 0.120 & 0.132 & 2133 & 0.132 & 0.112 & 0.106 \\
\hline HHI & 2498 & 0.107 & 0.066 & 0.037 & 0.100 & 0.292 & 365 & 0.113 & 0.068 & 0.100 & 2133 & 0.106 & 0.065 & 0.091 \\
\hline \multicolumn{15}{|c|}{ Characteristics of bank-firm relationship } \\
\hline B_MAIN*ENQUIRY & 2498 & 0.239 & 0.427 & 0 & 0 & 1 & 365 & 0.441 & 0.497 & 0 & 2133 & 0.204 & 0.403 & 0 \\
\hline B_MAIN & 2498 & 0.601 & 0.490 & 0 & 1 & 1 & 365 & 0.871 & 0.335 & 1 & 2133 & 0.555 & 0.497 & 1 \\
\hline B_CONTACT & 2498 & 3.805 & 1.327 & 1 & 4 & 9 & 365 & 3.564 & 1.236 & 4 & 2133 & 3.846 & 1.337 & 4 \\
\hline
\end{tabular}




\section{Table 3: Summary statistics: transactions with main-bank}

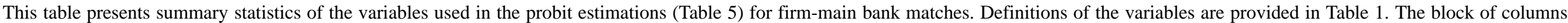

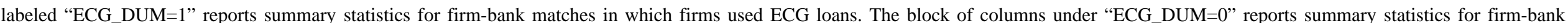
matches in which firms did not use ECG loans.

\begin{tabular}{|c|c|c|c|c|c|c|c|c|c|c|c|c|c|c|}
\hline \multirow{2}{*}{$\begin{array}{l}\text { B_MAIN }=1 \\
\end{array}$} & \multicolumn{6}{|c|}{ All } & \multicolumn{4}{|c|}{ ECG_DUM=1 } & \multicolumn{4}{|c|}{ ECG_DUM=0 } \\
\hline & $\mathrm{N}$ & mean & sd & $\min$ & $\mathrm{p} 50$ & $\max$ & $\mathrm{N}$ & mean & sd & $\mathrm{p} 50$ & $\mathrm{~N}$ & mean & sd & p50 \\
\hline \multicolumn{15}{|l|}{ Characteristics of credit guarantees } \\
\hline ECG_DUM & 1502 & 0.212 & 0.409 & 0 & 0 & 1 & 318 & 1.000 & 0.000 & 1 & 1184 & 0.000 & 0.000 & 0 \\
\hline RCG_DUM & 1502 & 0.426 & 0.495 & 0 & 0 & 1 & 318 & 0.783 & 0.413 & 1 & 1184 & 0.330 & 0.470 & 0 \\
\hline \multicolumn{15}{|l|}{ Firm characteristics } \\
\hline LOAN_ENQUIRY & 1502 & 0.397 & 0.490 & 0 & 0 & 1 & 318 & 0.506 & 0.501 & 1 & 1184 & 0.368 & 0.483 & 0 \\
\hline SCORE & 1502 & 55.147 & 6.469 & 31 & 54 & 87 & 318 & 51.116 & 4.411 & 51 & 1184 & 56.230 & 6.507 & 55 \\
\hline CAPRATIO_NG & 1502 & 0.051 & 0.221 & 0 & 0 & 1 & 318 & 0.088 & 0.284 & 0 & 1184 & 0.041 & 0.199 & 0 \\
\hline LOANRATIO & 1502 & 0.394 & 0.271 & 0.000 & 0.360 & 3.639 & 318 & 0.555 & 0.242 & 0.557 & 1184 & 0.350 & 0.262 & 0.311 \\
\hline lnSALES & 1502 & 7.435 & 1.642 & 0.000 & 7.304 & 14.352 & 318 & 6.676 & 1.212 & 6.615 & 1184 & 7.639 & 1.682 & 7.512 \\
\hline lnFIRMAGE & 1502 & 3.642 & 0.517 & 1.946 & 3.761 & 4.787 & 318 & 3.542 & 0.515 & 3.638 & 1184 & 3.669 & 0.514 & 3.784 \\
\hline IND1 & 1502 & 0.242 & 0.428 & 0 & 0 & 1 & 318 & 0.333 & 0.472 & 0 & 1184 & 0.217 & 0.412 & 0 \\
\hline IND2 & 1502 & 0.256 & 0.436 & 0 & 0 & 1 & 318 & 0.239 & 0.427 & 0 & 1184 & 0.260 & 0.439 & 0 \\
\hline IND3 & 1502 & 0.031 & 0.172 & 0 & 0 & 1 & 318 & 0.009 & 0.097 & 0 & 1184 & 0.036 & 0.187 & 0 \\
\hline IND4 & 1502 & 0.037 & 0.190 & 0 & 0 & 1 & 318 & 0.031 & 0.175 & 0 & 1184 & 0.039 & 0.193 & 0 \\
\hline IND5 & 1502 & 0.228 & 0.419 & 0 & 0 & 1 & 318 & 0.198 & 0.399 & 0 & 1184 & 0.236 & 0.425 & 0 \\
\hline IND6 & 1502 & 0.098 & 0.297 & 0 & 0 & 1 & 318 & 0.094 & 0.293 & 0 & 1184 & 0.099 & 0.299 & 0 \\
\hline IND7 & 1502 & 0.019 & 0.138 & 0 & 0 & 1 & 318 & 0.019 & 0.136 & 0 & 1184 & 0.019 & 0.138 & 0 \\
\hline IND8 & 1502 & 0.004 & 0.063 & 0 & 0 & 1 & 318 & 0.003 & 0.056 & 0 & 1184 & 0.004 & 0.065 & 0 \\
\hline IND9 & 1502 & 0.086 & 0.280 & 0 & 0 & 1 & 318 & 0.072 & 0.259 & 0 & 1184 & 0.090 & 0.286 & 0 \\
\hline \multicolumn{15}{|l|}{ Bank characteristics } \\
\hline B_REGIONAL & 1502 & 0.744 & 0.436 & 0 & 1 & 1 & 318 & 0.874 & 0.332 & 1 & 1184 & 0.709 & 0.454 & 1 \\
\hline B_REGIONAL*BIS & 1502 & 8.176 & 5.725 & -11.570 & 10.100 & 35.170 & 318 & 9.664 & 4.777 & 10.340 & 1184 & 7.776 & 5.892 & 10.100 \\
\hline BIS & 1502 & 11.151 & 3.181 & -11.570 & 11.420 & 35.170 & 318 & 11.063 & 3.078 & 10.710 & 1184 & 11.174 & 3.208 & 11.440 \\
\hline BANKSHARE & 1502 & 0.158 & 0.120 & 0.000 & 0.119 & 0.462 & 318 & 0.169 & 0.123 & 0.153 & 1184 & 0.155 & 0.120 & 0.118 \\
\hline HHI & 1502 & 0.112 & 0.067 & 0.037 & 0.100 & 0.292 & 318 & 0.117 & 0.069 & 0.103 & 1184 & 0.110 & 0.066 & 0.100 \\
\hline \multicolumn{15}{|c|}{ Characteristics of bank-firm relationship } \\
\hline B_MAIN*ENQUIRY & 1502 & 0.397 & 0.490 & 0 & 0 & 1 & 318 & 0.506 & 0.501 & 1 & 1184 & 0.368 & 0.483 & 0 \\
\hline B_MAIN & 1502 & 1.000 & 0.000 & 1 & 1 & 1 & 318 & 1.000 & 0.000 & 1 & 1184 & 1.000 & 0.000 & 1 \\
\hline B_CONTACT & 1502 & 3.607 & 1.295 & 1 & 4 & 9 & 318 & 3.522 & 1.255 & 4 & 1184 & 3.630 & 1.305 & 4 \\
\hline
\end{tabular}




\section{Table 4: Summary statistics: transactions with non-main-bank}

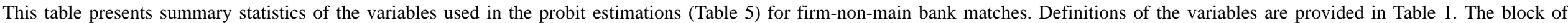

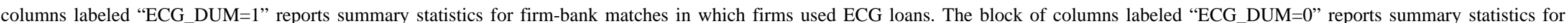
firm-bank matches in which firms did not use ECG loans.

\begin{tabular}{|c|c|c|c|c|c|c|c|c|c|c|c|c|c|c|}
\hline \multirow{2}{*}{$\underline{\text { B_MAIN }=0}$} & \multicolumn{6}{|c|}{ All } & \multicolumn{4}{|c|}{$\overline{\text { ECG_DUM=1 }}$} & \multicolumn{4}{|c|}{$\overline{E \text { ECG_DUM=0 }}$} \\
\hline & $\mathrm{N}$ & mean & sd & $\min$ & $\mathrm{p} 50$ & $\max$ & $\mathrm{N}$ & mean & $\mathrm{sd}$ & p50 & $\mathrm{N}$ & mean & $\mathrm{sd}$ & p50 \\
\hline \multicolumn{15}{|l|}{ Characteristics of credit guarantees } \\
\hline ECG_DUM & 996 & 0.047 & 0.212 & 0 & 0 & 1 & 47 & 1.000 & 0.000 & 1 & 949 & 0.000 & 0.000 & 0 \\
\hline RCG_DUM & 996 & 0.345 & 0.476 & 0 & 0 & 1 & 47 & 0.617 & 0.491 & 1 & 949 & 0.332 & 0.471 & 0 \\
\hline \multicolumn{15}{|l|}{ Firm characteristics } \\
\hline LOAN_ENQUIRY & 996 & 0.286 & 0.452 & 0 & 0 & 1 & 47 & 0.170 & 0.380 & 0 & 949 & 0.292 & 0.455 & 0 \\
\hline SCORE & 996 & 55.408 & 6.598 & 27 & 54 & 87 & 47 & 53.298 & 4.242 & 52 & 949 & 55.512 & 6.678 & 55 \\
\hline CAPRATIO_NG & 996 & 0.043 & 0.203 & 0 & 0 & 1 & 47 & 0.021 & 0.146 & 0 & 949 & 0.044 & 0.206 & 0 \\
\hline LOANRATIO & 996 & 0.392 & 0.258 & 0.000 & 0.360 & 2.026 & 47 & 0.489 & 0.224 & 0.495 & 949 & 0.387 & 0.258 & 0.352 \\
\hline $\operatorname{lnSALES}$ & 996 & 7.559 & 1.666 & 0.000 & 7.374 & 13.875 & 47 & 7.041 & 1.195 & 6.835 & 949 & 7.585 & 1.682 & 7.413 \\
\hline lnFIRMAGE & 996 & 3.630 & 0.515 & 1.946 & 3.761 & 4.787 & 47 & 3.495 & 0.590 & 3.664 & 949 & 3.637 & 0.510 & 3.761 \\
\hline IND1 & 996 & 0.224 & 0.417 & 0 & 0 & 1 & 47 & 0.191 & 0.398 & 0 & 949 & 0.226 & 0.418 & 0 \\
\hline IND2 & 996 & 0.258 & 0.438 & 0 & 0 & 1 & 47 & 0.234 & 0.428 & 0 & 949 & 0.259 & 0.438 & 0 \\
\hline IND3 & 996 & 0.035 & 0.184 & 0 & 0 & 1 & 47 & 0.106 & 0.312 & 0 & 949 & 0.032 & 0.175 & 0 \\
\hline IND4 & 996 & 0.036 & 0.187 & 0 & 0 & 1 & 47 & 0.021 & 0.146 & 0 & 949 & 0.037 & 0.189 & 0 \\
\hline IND5 & 996 & 0.227 & 0.419 & 0 & 0 & 1 & 47 & 0.170 & 0.380 & 0 & 949 & 0.230 & 0.421 & 0 \\
\hline IND6 & 996 & 0.095 & 0.294 & 0 & 0 & 1 & 47 & 0.149 & 0.360 & 0 & 949 & 0.093 & 0.290 & 0 \\
\hline IND7 & 996 & 0.021 & 0.144 & 0 & 0 & 1 & 47 & 0.021 & 0.146 & 0 & 949 & 0.021 & 0.144 & 0 \\
\hline IND8 & 996 & 0.005 & 0.071 & 0 & 0 & 1 & 47 & 0.000 & 0.000 & 0 & 949 & 0.005 & 0.072 & 0 \\
\hline IND9 & 996 & 0.098 & 0.298 & 0 & 0 & 1 & 47 & 0.106 & 0.312 & 0 & 949 & 0.098 & 0.297 & 0 \\
\hline \multicolumn{15}{|l|}{ Bank characteristics } \\
\hline B_REGIONAL & 996 & 0.673 & 0.469 & 0 & 1 & 1 & 47 & 0.660 & 0.479 & 1 & 949 & 0.673 & 0.469 & 1 \\
\hline B_REGIONAL*BIS & 996 & 7.236 & 6.146 & -11.570 & 9.510 & 35.300 & 47 & 7.368 & 5.734 & 9.480 & 949 & 7.229 & 6.169 & 9.510 \\
\hline BIS & 996 & 11.055 & 3.576 & -11.570 & 11.210 & 35.300 & 47 & 11.120 & 2.162 & 10.780 & 949 & 11.052 & 3.633 & 11.210 \\
\hline BANKSHARE & 996 & 0.102 & 0.094 & 0.000 & 0.074 & 0.444 & 47 & 0.100 & 0.082 & 0.072 & 949 & 0.103 & 0.095 & 0.074 \\
\hline HHI & 996 & 0.099 & 0.063 & 0.037 & 0.080 & 0.292 & 47 & 0.083 & 0.054 & 0.066 & 949 & 0.100 & 0.063 & 0.080 \\
\hline \multicolumn{15}{|c|}{ Characteristics of bank-firm relationship } \\
\hline B_MAIN*ENQUIRY & 996 & 0.000 & 0.000 & 0 & 0 & 0 & 47 & 0.000 & 0.000 & 0 & 949 & 0.000 & 0.000 & 0 \\
\hline B_MAIN & 996 & 0.000 & 0.000 & 0 & 0 & 0 & 47 & 0.000 & 0.000 & 0 & 949 & 0.000 & 0.000 & 0 \\
\hline B_CONTACT & 996 & 4.103 & 1.319 & 1 & 4 & 9 & 47 & 3.851 & 1.063 & 4 & 949 & 4.116 & 1.329 & 4 \\
\hline
\end{tabular}




\section{Table 5: Probit estimations on the determinants of the use of ECG loans}

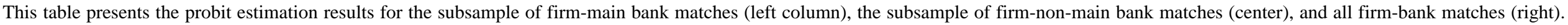
Definitions of the variables are provided in Table $1 . * * *, * *, *$ indicate a significance level of 1,5 , and $10 \%$, respectively.

\section{Estimation method: Probit \\ Dependent variable: ECG_DUM \\ Characteristics of credit guarantees}

$$
\text { RCG_DUM }
$$

\section{Firm characteristics}

LOAN_ENQUIRY
SHARPERATIO
SCORE
CAPRATIO_NG
LOANRATIO
InSALES
InFIRMAGE

Bank characteristics

B_REGIONAL
B_REGIONAL*BIS
BIS
BANKSHARE
HHI

Characteristics of bank-firm relationship

\begin{tabular}{ccc}
\multicolumn{3}{c}{ B_MAIN=1 } \\
\hline Coef. & Std. Err & z \\
\hline & & \\
$0.685^{* * *}$ & 0.094 & 7.310
\end{tabular}

\begin{tabular}{crc} 
& B_MAIN=0 & \\
\hline Coef. & Std. Err & z \\
\hline
\end{tabular}

$0.379^{* *}$

0.165

2.300

\section{$0.196 \quad-1.900$}

$0.084-1.070$

$\begin{array}{rrr}0.220 & 0.086 & 2.560 \\ -0.025 & 0.046 & -0.530\end{array}$

$-0.043^{* * *}$

$-0.595^{* * *}$

$0.770^{* * *}$

$-0.093^{* * *}$

$-0.054$

$0.010 \quad-4.150$

$0.183-3.240$

$0.181 \quad 4.260$

$0.036 \quad-2.540$

$0.089-0.610$

$\begin{array}{lll}-2.582^{* *} & 1.253 \quad-2.060\end{array}$

$0.240^{* *} \quad 0.110 \quad 2.170$

$-0.239^{* *}$

0.743

-1.542 *

$0.110 \quad-2.180$

$0.499 \quad 1.490$

$0.937 \quad-1.650$

B_MAIN*ENQUIRY

B_MAIN

B_CONTACT

constant

$-0.034$

$4.201^{* * *}$

0.033

$-1.040$

2.910

$-0.160^{* *}$

$3.891^{* *}$

1.948

$-0.740$

$0.471--1.790$

$0.370 \quad 1.960$

$0.064 \quad-0.400$

$0.158 \quad-0.880$

$-4.099^{* * *}$

$0.352^{* * *}$

0.491

$-3.155^{* *}$

$\begin{array}{lc}1.502 & -2.730 \\ 0.133 & 2.660 \\ 0.130 & -2.650 \\ 0.997 & 0.490 \\ 1.600 & -1.970\end{array}$

Industry_dummies

\begin{tabular}{lrrr}
\hline Number of Observations & 1502 & 991 & 2498 \\
LRchi2 & 338.6 & 51.43 & 501.73 \\
Prob > chi2 & 0 & 0 & 0 \\
Pseudo R2 & 0.22 & 0.14 & 0.24 \\
Log likelihood & -606.07 & -163.44 & -788.09 \\
\hline \hline
\end{tabular}

\begin{tabular}{crc}
\hline \multicolumn{2}{c}{ Entire sample } & \\
\hline Coef. & Std. Err & $\mathrm{z}$ \\
\hline $0.621^{* * *}$ & 0.080 & 7.730
\end{tabular}

\begin{tabular}{|c|c|c|}
\hline$-0.439^{* *}$ & 0.190 & -2.300 \\
\hline-0.039 & 0.040 & -0.990 \\
\hline$-0.035^{* * *}$ & 0.009 & -3.920 \\
\hline$-0.612^{* * *}$ & 0.163 & -3.750 \\
\hline $0.769^{* * *}$ & 0.159 & 4.830 \\
\hline$-0.079^{* * *}$ & 0.031 & -2.530 \\
\hline-0.074 & 0.076 & -0.970 \\
\hline$-3.292^{* * *}$ & 0.964 & -3.410 \\
\hline $0.294^{* * *}$ & 0.085 & 3.460 \\
\hline$-0.292^{* * *}$ & 0.084 & -3.470 \\
\hline $0.833^{* *}$ & 0.431 & 1.930 \\
\hline$-1.894^{* *}$ & 0.786 & -2.410 \\
\hline $0.663^{* * *}$ & 0.205 & 3.230 \\
\hline $0.645^{* * *}$ & 0.103 & 6.270 \\
\hline$-0.064^{* *}$ & 0.029 & -2.200 \\
\hline & & \\
\hline
\end{tabular}

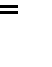




\section{Table 6: Treatment effect estimations on loan availability for, and ex-post performance of, ECG loan users}

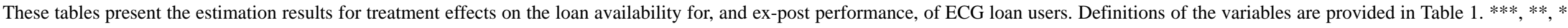
indicate a significance level of 1,5 , and $10 \%$, respectively.

\section{(a) Entire sample}

\begin{tabular}{|c|c|c|c|c|c|c|c|}
\hline \multicolumn{8}{|l|}{$\begin{array}{l}\text { Entire sample } \\
\text {. }\end{array}$} \\
\hline Variable & & Treated & Controls & Difference & & S.E. & T-stat \\
\hline \multirow[t]{2}{*}{ ECG_LOAN_RATIO } & Unmatched & 0.103 & 0.000 & 0.103 & $* * *$ & 0.003 & 33.770 \\
\hline & ATT & 0.103 & 0.000 & 0.103 & $* * *$ & 0.008 & 13.610 \\
\hline \multirow[t]{2}{*}{ dB_LOAN_RATIO } & Unmatched & 0.050 & 0.008 & 0.042 & $* * *$ & 0.008 & 5.380 \\
\hline & ATT & 0.050 & 0.000 & 0.050 & $* * *$ & 0.010 & 4.850 \\
\hline \multirow[t]{2}{*}{ dB_TLOAN_RATIO } & Unmatched & 0.042 & 0.009 & 0.033 & $* * *$ & 0.011 & 3.120 \\
\hline & ATT & 0.042 & 0.001 & 0.041 & $* * *$ & 0.013 & 3.250 \\
\hline \multirow[t]{2}{*}{ dLOAN_RATIO } & Unmatched & 0.026 & 0.003 & 0.022 & $* * *$ & 0.007 & 3.240 \\
\hline & ATT & 0.026 & -0.010 & 0.036 & $* * *$ & 0.009 & 3.920 \\
\hline \multirow[t]{2}{*}{ dSHORT_RATIO } & Unmatched & -0.013 & -0.006 & -0.007 & & 0.005 & -1.340 \\
\hline & ATT & -0.013 & -0.015 & 0.002 & & 0.007 & 0.230 \\
\hline \multirow[t]{2}{*}{ dLONG_RATIO } & Unmatched & 0.039 & 0.009 & 0.029 & $* * *$ & 0.005 & 5.760 \\
\hline & ATT & 0.039 & 0.005 & 0.034 & $* * *$ & 0.007 & 4.810 \\
\hline \multirow[t]{2}{*}{ dCASHRATIO } & Unmatched & 0.014 & 0.007 & 0.006 & & 0.005 & 1.340 \\
\hline & ATT & 0.014 & 0.003 & 0.010 & & 0.006 & 1.590 \\
\hline \multirow[t]{2}{*}{ dTANGIBLERATIO } & Unmatched & -0.006 & 0.000 & -0.006 & & 0.005 & -1.240 \\
\hline & ATT & -0.006 & -0.001 & -0.005 & & 0.006 & -0.800 \\
\hline \multirow[t]{2}{*}{ dROA } & Unmatched & -0.020 & -0.013 & -0.008 & & 0.006 & -1.380 \\
\hline & ATT & -0.020 & -0.005 & -0.015 & & 0.010 & -1.530 \\
\hline \multirow[t]{2}{*}{ dSALESRATIO } & Unmatched & -0.141 & -0.018 & -0.123 & $* * *$ & 0.030 & -4.060 \\
\hline & ATT & -0.141 & -0.012 & -0.129 & $* * *$ & 0.039 & -3.270 \\
\hline \multirow[t]{2}{*}{ dCOSTRATIO } & Unmatched & -0.120 & -0.005 & -0.115 & $* * *$ & 0.030 & -3.850 \\
\hline & ATT & -0.120 & -0.006 & -0.114 & $* * *$ & 0.040 & -2.880 \\
\hline \multirow[t]{2}{*}{ dSCORE } & Unmatched & -1.132 & -0.975 & -0.157 & & 0.166 & -0.940 \\
\hline & ATT & -1.132 & -0.499 & -0.633 & $* * *$ & 0.214 & -2.950 \\
\hline \multirow[t]{2}{*}{ dlnEMP } & Unmatched & -0.027 & -0.013 & -0.013 & & 0.018 & -0.740 \\
\hline & ATT & -0.027 & -0.018 & -0.009 & & 0.018 & -0.520 \\
\hline \multirow[t]{2}{*}{ dRATE } & Unmatched & -0.003 & -0.002 & -0.001 & & 0.004 & -0.270 \\
\hline & ATT & -0.003 & -0.001 & -0.002 & & 0.004 & -0.620 \\
\hline
\end{tabular}


(b) Subsample of firm-main bank matches

\begin{tabular}{|c|c|c|c|c|c|c|c|}
\hline \multicolumn{8}{|l|}{$\overline{\text { B_MAIN=1 }}$} \\
\hline \multicolumn{2}{|l|}{ Variable } & Treated & Controls & \multicolumn{2}{|l|}{ Difference } & \multirow[t]{2}{*}{ S.E. } & T-stat \\
\hline \multirow[t]{2}{*}{ ECG_LOAN_RATIO } & Unmatched & 0.107 & 0.000 & 0.107 & $* * *$ & & 26.600 \\
\hline & ATT & 0.107 & 0.000 & 0.107 & $* * *$ & 0.008 & 12.870 \\
\hline \multirow[t]{2}{*}{ dB_LOAN_RATIO } & Unmatched & 0.049 & 0.007 & 0.042 & $* * *$ & 0.009 & 4.620 \\
\hline & ATT & 0.049 & -0.002 & 0.050 & $* * *$ & 0.012 & 4.360 \\
\hline \multirow[t]{2}{*}{ dB_TLOAN_RATIO } & Unmatched & 0.044 & 0.008 & 0.036 & $* * *$ & 0.012 & 3.120 \\
\hline & ATT & 0.044 & 0.003 & 0.041 & $* * *$ & 0.014 & 2.980 \\
\hline \multirow[t]{2}{*}{ dLOAN_RATIO } & Unmatched & 0.024 & 0.004 & 0.020 & $* * *$ & 0.008 & 2.660 \\
\hline & ATT & 0.024 & -0.010 & 0.034 & $* * *$ & 0.010 & 3.390 \\
\hline \multirow[t]{2}{*}{ dSHORT_RATIO } & Unmatched & -0.015 & -0.004 & -0.011 & $*$ & 0.006 & -1.770 \\
\hline & ATT & -0.015 & -0.014 & -0.001 & & 0.008 & -0.080 \\
\hline \multirow[t]{2}{*}{ dLONG_RATIO } & Unmatched & 0.039 & 0.008 & 0.031 & $* * *$ & 0.006 & 5.540 \\
\hline & ATT & 0.039 & 0.005 & 0.034 & $* * *$ & 0.008 & 4.570 \\
\hline \multirow[t]{2}{*}{ dCASHRATIO } & Unmatched & 0.015 & 0.007 & 0.008 & & 0.005 & 1.420 \\
\hline & ATT & 0.015 & 0.003 & 0.011 & * & 0.007 & 1.690 \\
\hline \multirow[t]{2}{*}{ dTANGIBLERATIO } & Unmatched & -0.004 & -0.003 & -0.001 & & 0.006 & -0.170 \\
\hline & ATT & -0.004 & -0.002 & -0.002 & & 0.007 & -0.260 \\
\hline \multirow[t]{2}{*}{ dROA } & Unmatched & -0.020 & -0.011 & -0.009 & & 0.007 & -1.390 \\
\hline & ATT & -0.020 & -0.005 & -0.015 & & 0.011 & -1.350 \\
\hline \multirow[t]{2}{*}{ dSALESRATIO } & Unmatched & -0.151 & -0.014 & -0.137 & $* * *$ & 0.035 & -3.900 \\
\hline & ATT & -0.151 & -0.013 & -0.138 & $* * *$ & 0.044 & -3.100 \\
\hline \multirow[t]{2}{*}{ dCOSTRATIO } & Unmatched & -0.131 & -0.003 & -0.128 & $* * *$ & 0.035 & -3.670 \\
\hline & ATT & -0.131 & -0.008 & -0.123 & $* * *$ & 0.045 & -2.740 \\
\hline \multirow[t]{2}{*}{ dSCORE } & Unmatched & -1.140 & -0.930 & -0.210 & & 0.184 & -1.140 \\
\hline & ATT & -1.140 & -0.506 & -0.634 & $* * *$ & 0.234 & -2.710 \\
\hline \multirow[t]{2}{*}{ dlnEMP } & Unmatched & -0.023 & -0.007 & -0.016 & & 0.021 & -0.760 \\
\hline & ATT & -0.023 & -0.020 & -0.003 & & 0.021 & -0.130 \\
\hline \multirow[t]{2}{*}{ dRATE } & Unmatched & -0.002 & -0.004 & 0.002 & & 0.005 & 0.370 \\
\hline & ATT & -0.002 & -0.001 & -0.001 & & 0.004 & -0.210 \\
\hline
\end{tabular}


(c) Subsample of firm-non-main bank matches

\begin{tabular}{|c|c|c|c|c|c|c|c|}
\hline \multicolumn{8}{|l|}{$\overline{\text { B_MAIN }=0}$} \\
\hline \multirow{3}{*}{$\begin{array}{l}\text { Variable } \\
\text { ECG_LOAN_RATIO }\end{array}$} & & Treated & Controls & Difference & & S.E. & T-stat \\
\hline & Unmatched & 0.072 & 0.000 & 0.072 & $* * *$ & 0.003 & 24.250 \\
\hline & ATT & 0.072 & 0.000 & 0.072 & $* * *$ & 0.015 & 4.880 \\
\hline \multirow[t]{2}{*}{ dB_LOAN_RATIO } & Unmatched & 0.057 & 0.007 & 0.050 & $* * *$ & 0.018 & 2.730 \\
\hline & ATT & 0.057 & 0.004 & 0.053 & $* * *$ & 0.019 & 2.780 \\
\hline \multirow[t]{2}{*}{ dB_TLOAN_RATIO } & Unmatched & 0.023 & 0.013 & 0.010 & & 0.029 & 0.330 \\
\hline & $\mathrm{ATT}$ & 0.023 & 0.009 & 0.014 & & 0.022 & 0.640 \\
\hline \multirow[t]{2}{*}{ dLOAN_RATIO } & Unmatched & 0.034 & 0.007 & 0.026 & & 0.017 & 1.510 \\
\hline & ATT & 0.034 & 0.001 & 0.033 & $*$ & 0.019 & 1.700 \\
\hline \multirow[t]{2}{*}{ dSHORT_RATIO } & Unmatched & -0.001 & -0.008 & 0.007 & & 0.013 & 0.570 \\
\hline & ATT & -0.001 & -0.018 & 0.017 & & 0.014 & 1.180 \\
\hline \multirow[t]{2}{*}{ dLONG_RATIO } & Unmatched & 0.035 & 0.016 & 0.019 & & 0.013 & 1.420 \\
\hline & $\mathrm{ATT}$ & 0.035 & 0.019 & 0.016 & & 0.018 & 0.890 \\
\hline \multirow[t]{2}{*}{ dCASHRATIO } & Unmatched & 0.007 & 0.008 & -0.001 & & 0.013 & -0.070 \\
\hline & $\mathrm{ATT}$ & 0.007 & 0.007 & 0.000 & & 0.021 & 0.000 \\
\hline \multirow[t]{2}{*}{ dTANGIBLERATIO } & Unmatched & -0.021 & 0.001 & -0.022 & $*$ & 0.013 & -1.800 \\
\hline & $\mathrm{ATT}$ & -0.021 & -0.002 & -0.019 & $*$ & 0.010 & -1.990 \\
\hline \multirow[t]{2}{*}{ dROA } & Unmatched & -0.021 & -0.017 & -0.005 & & 0.018 & -0.250 \\
\hline & ATT & -0.021 & -0.023 & 0.001 & & 0.014 & 0.100 \\
\hline \multirow[t]{2}{*}{ dSALESRATIO } & Unmatched & -0.074 & -0.037 & -0.037 & & 0.074 & -0.500 \\
\hline & ATT & -0.074 & -0.051 & -0.023 & & 0.071 & -0.320 \\
\hline \multirow[t]{2}{*}{ dCOSTRATIO } & Unmatched & -0.053 & -0.021 & -0.032 & & 0.073 & -0.440 \\
\hline & ATT & -0.053 & -0.028 & -0.024 & & 0.068 & -0.350 \\
\hline \multirow[t]{2}{*}{ dSCORE } & Unmatched & -1.069 & -1.092 & 0.023 & & 0.484 & 0.050 \\
\hline & ATT & -1.069 & -0.944 & -0.125 & & 0.444 & -0.280 \\
\hline \multirow[t]{2}{*}{$d \ln E M P$} & Unmatched & -0.051 & -0.025 & -0.026 & & 0.042 & -0.630 \\
\hline & ATT & -0.051 & -0.024 & -0.027 & & 0.022 & -1.250 \\
\hline \multirow[t]{2}{*}{ dRATE } & Unmatched & -0.011 & -0.001 & -0.010 & & 0.007 & -1.400 \\
\hline & ATT & -0.011 & 0.000 & -0.011 & & 0.007 & -1.450 \\
\hline
\end{tabular}




\section{Table 7. OLS estimations on loan availability}

These tables present OLS estimation results on loan availability. Definitions of the variables are provided in Table 1. ***, $^{* *}$, * indicate a significance level of 1 , 5 , and $10 \%$, respectively.

(a) Subsample of firm-main bank matches

\begin{tabular}{|c|c|c|c|c|}
\hline \multirow{3}{*}{$\frac{\text { Estimation method: OLS }}{\text { Dependent variable: }}$} & \multicolumn{2}{|c|}{ "dB_LOAN_RATIO } & \multicolumn{2}{|c|}{ "dB_TLOAN_RATIO } \\
\hline & \multicolumn{2}{|c|}{ B_MAIN=1 } & \multicolumn{2}{|c|}{ B_MAIN=1 } \\
\hline & Coef. & $\mathrm{t}$ & Coef. & $\mathrm{t}$ \\
\hline \multicolumn{5}{|l|}{ Characteristics of credit guarantees } \\
\hline ECG_LOAN_RATIO & $0.444 * * *$ & 7.160 & $0.256 * * *$ & 3.230 \\
\hline RP_DUM & 0.002 & 0.250 & 0.000 & 0.030 \\
\hline \multicolumn{5}{|l|}{ Firm characteristics } \\
\hline LOAN_ENQUIRY & $0.023 * * *$ & 2.880 & 0.016 & 1.590 \\
\hline SHARPERATIO & -0.001 & -0.170 & -0.003 & -0.490 \\
\hline SCORE & 0.000 & -0.370 & 0.001 & 0.840 \\
\hline CAPRATIO_NG & 0.020 & 0.930 & -0.020 & -0.740 \\
\hline LOANRATIO & $-0.058 * * *$ & -3.260 & -0.024 & -1.040 \\
\hline $\operatorname{lnSALES}$ & 0.003 & 0.790 & 0.004 & 0.940 \\
\hline $\operatorname{lnFIRMAGE}$ & 0.004 & 0.450 & $-0.018 *$ & -1.680 \\
\hline \multicolumn{5}{|l|}{ Bank characteristics } \\
\hline B_REGIONAL & 0.009 & 0.110 & 0.005 & 0.050 \\
\hline B_REGIONAL*BIS & 0.001 & 0.190 & 0.002 & 0.260 \\
\hline BIS & -0.003 & -0.360 & -0.003 & -0.290 \\
\hline BANKSHARE & 0.037 & 0.810 & -0.005 & -0.090 \\
\hline $\mathrm{HHI}$ & -0.084 & -1.020 & $-0.206 * *$ & -1.960 \\
\hline \multicolumn{5}{|c|}{ Characteristics of bank-firm relationship } \\
\hline B_MAIN*ENQUIRY & 0.000 & -0.160 & 0.003 & 0.880 \\
\hline constant & 0.012 & 0.120 & -0.032 & -0.250 \\
\hline Industry dummies & Yes & & Yes & \\
\hline Number of observations & 931 & & 931 & \\
\hline F value & 3.51 & & 1.58 & \\
\hline Prob $>$ F & 0 & & 0.04 & \\
\hline Adj R-squared & 0.06 & & 0.01 & \\
\hline
\end{tabular}


(b) Subsample of firm-non-main bank matches

\begin{tabular}{|c|c|c|c|c|}
\hline \multirow{2}{*}{$\begin{array}{l}\text { Estimation method: OLS } \\
\text { Dependent variable: }\end{array}$} & \multicolumn{2}{|c|}{$\begin{array}{c}\text { dB_LOAN_RATIO } \\
\text { B_MAIN=0 }\end{array}$} & \multicolumn{2}{|c|}{$\begin{array}{c}\text { dB_TLOAN_RATIO } \\
\text { B_MAIN=0 }\end{array}$} \\
\hline & Coef. & $\mathrm{t}$ & Coef. & $\mathrm{t}$ \\
\hline \multicolumn{5}{|l|}{ Characteristics of credit guarantees } \\
\hline ECG_LOAN_RATIO & $0.905 * * *$ & 4.730 & 0.026 & 0.090 \\
\hline RP_DUM & $-0.041 * * *$ & -4.230 & -0.020 & -1.300 \\
\hline \multicolumn{5}{|l|}{ Firm characteristics } \\
\hline LOAN_ENQUIRY & 0.001 & 0.070 & 0.000 & 0.020 \\
\hline SHARPERATIO & 0.002 & 0.480 & 0.001 & 0.110 \\
\hline SCORE & 0.000 & 0.570 & 0.001 & 0.590 \\
\hline CAPRATIO_NG & -0.038 & -1.590 & $-0.084 * *$ & -2.260 \\
\hline LOANRATIO & $0.054 * * *$ & 2.630 & 0.036 & 1.120 \\
\hline $\operatorname{lnSALES}$ & -0.002 & -0.650 & 0.000 & 0.010 \\
\hline lnFIRMAGE & -0.008 & -0.930 & -0.009 & -0.630 \\
\hline \multicolumn{5}{|l|}{ Bank characteristics } \\
\hline B_REGIONAL & -0.096 & -1.210 & 0.046 & 0.370 \\
\hline B_REGIONAL*BIS & 0.009 & 1.260 & -0.003 & -0.280 \\
\hline BIS & -0.008 & -1.150 & 0.002 & 0.220 \\
\hline BANKSHARE & 0.038 & 0.790 & 0.004 & 0.060 \\
\hline HHI & $-0.118 *$ & -1.650 & -0.132 & -1.170 \\
\hline \multicolumn{5}{|c|}{ Characteristics of bank-firm relationship } \\
\hline B_MAIN*ENQUIRY & -0.003 & -0.860 & -0.006 & -1.250 \\
\hline constant & 0.110 & 0.990 & 0.214 & 1.230 \\
\hline Industry dummies & Yes & & Yes & \\
\hline Number of observations & 625 & & 625 & \\
\hline F value & 2.75 & & 1.32 & \\
\hline Prob $>$ F & 0 & & 0.14 & \\
\hline Adj R-squared & 0.06 & & 0.01 & \\
\hline
\end{tabular}

